The Black Hole in Isaiah

A Study of Exile as a Literary Theme

Poulsen, Frederik

DOI:

10.1628/978-3-16-156863-3

Publication date:

2019

Document license:

Unspecified

Citation for published version (APA):

Poulsen, F. (2019). The Black Hole in Isaiah: A Study of Exile as a Literary Theme. Mohr Siebeck. Forschungen zum Alten Testament Vol. 125 https://doi.org/10.1628/978-3-16-156863-3 


\section{FREDERIK POULSEN}

\section{The Black Hole in Isaiah}

Forschungen

zum Alten Testament

125

Mohr Siebeck 


\section{Forschungen zum Alten Testament}

Edited by

Konrad Schmid (Zürich) · Mark S. Smith (Princeton)

Hermann Spieckermann (Göttingen) · Andrew Teeter (Harvard)

125

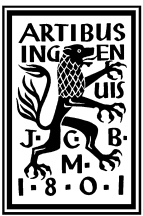



Frederik Poulsen

\title{
The Black Hole in Isaiah
}

\author{
A Study of Exile as a Literary Theme
}

Mohr Siebeck 
Frederik Poulsen, born 1984; 2014 PhD; currently Assistant Professor of Old Testament at the University of Copenhagen.

Denne afhandling er af Det Teologiske Fakultet ved Københavns Universitet antaget til offentligt at forsvares for den teologiske doktorgrad.

Dekan Kirsten Busch Nielsen

København, den 9. juli 2018

Forsvaret finder sted fredag den 29. marts 2019 kl. 13.00 på Det Teologiske Fakultet, Københavns Universitet, aud. 9A.0.01, Karen Blixens Plads 16, 2300 København S.

The Faculty of Theology, University of Copenhagen, has accepted this dissertation for public defense for the doctoral degree in theology.

Dean Kirsten Busch Nielsen

Copenhagen, 9 July 2018

The defense takes place Friday 29 March 2019 at 13.00 at The Faculty of Theology, University of Copenhagen, Aud. 9A.0.01, Karen Blixens Plads 16, DK-2300 Copenhagen S.

ISBN 978-3-16-156862-6 / eISBN 978-3-16-156863-3

DOI 10.1628/978-3-16-156863-3

ISSN 0940-4155 / eISSN 2568-8359 (Forschungen zum Alten Testament)

The Deutsche Nationalbibliothek lists this publication in the Deutsche Nationalbibliographie; detailed bibliographic data are available at $h t t p: / / d n b . d n b . d e$.

(C) 2019 Mohr Siebeck, Tübingen, Germany. www.mohrsiebeck.com

This book may not be reproduced, in whole or in part, in any form (beyond that permitted by copyright law) without the publisher's written permission. This applies particularly to reproductions, translations and storage and processing in electronic systems.

The book was printed on non-aging paper by Gulde Druck in Tübingen, and bound by Großbuchbinderei Spinner in Ottersweier.

Printed in Germany. 
Til Maren 



\section{Preface}

The present monograph was written between July 2015 and November 2017. It was submitted in December 2017 to the Faculty of Theology at the University of Copenhagen for evaluation with the intent of defending it for the doctoral degree (dr.theol.). In July 2018 the Academic Council accepted it for defense. The oral defense will take place in March 2019. I am grateful to the members of the assessment committee Ulrich Berges, Lena-Sofia Tiemeyer, and Jesper Høgenhagen for their evaluation and to the series editors of FAT for accepting this work for publication. With the permission of the dean, a number of small errors in the original manuscript have been corrected.

The monograph was written thanks to a postdoctoral scholarship from the Independent Research Fund Denmark and its Sapere Aude program. The generous grant has offered me completely undisturbed time for studying the poetically rich and theologically challenging vision of Isaiah, arguably the most exciting book of the Bible. I did not think scholarships like these still existed, but they do, and I am very grateful to have been the recipient of one.

My research was carried out at the Department for Biblical Exegesis at the Faculty of Theology, University of Copenhagen. I would like to thank my colleagues for their pleasant and inspiring company over the years. I am grateful to Hermann Spieckermann who first encouraged me to explore exile in Isaiah and Francis Landy who read and discussed an early version of the book. Parts of the initial chapters were written during my research stay at the Hebrew University of Jerusalem in the Spring of 2016, and the manuscript was completed during my stay at the University of Bonn in the Fall of 2017. I would like to thank my local hosts, Ronnie Goldstein (Jerusalem) and Ulrich Berges (Bonn), for hospitality and stimulating talks. I am particularly thankful to Sarah Hussell for the excellent effort in proofreading and improving my English.

Family and friends have continuously supported and encouraged me during the work on this book. I am most grateful to my wife Maren and our children Johan, Samuel, and Ada for their love and care. Living with you, Maren, is like eating raisin cakes and apples all day long. This book is for you.

Frederik Poulsen

October 2018 



\section{Contents}

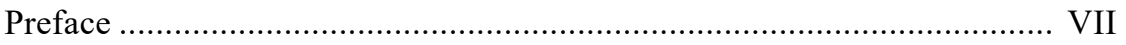

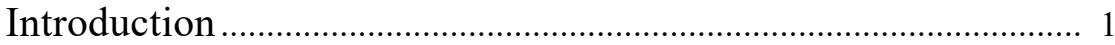

Approaches to the study of exile ................................................................. 2

Recent studies on exile in Isaiah .............................................................. 7

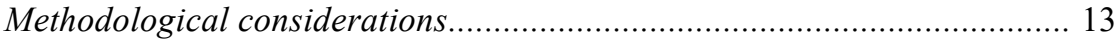

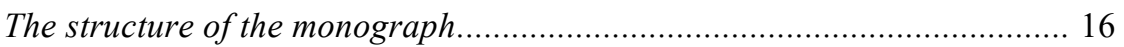

Chapter 1. Entering into the black hole ............................................ 19

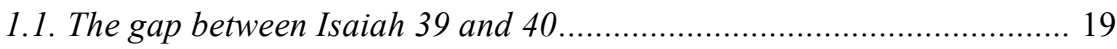

1.2. Entering down into Sheol (Isaiah 5:11-17) ......................................... 29

1.2.1. Isaiah 5:11-17: Text and translation........................................... 32

1.2.2. Isaiah 5:11-12: Woe to the drunkards who neglect YHWH......... 33

1.2.3. Isaiah 5:13-17: Exile, death, and a ruined city ............................ 35

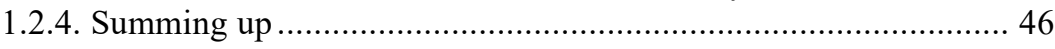

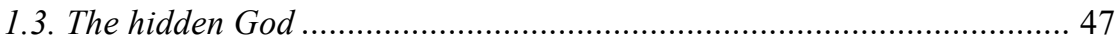

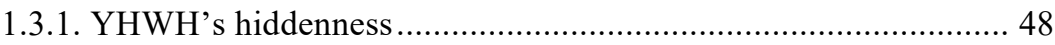

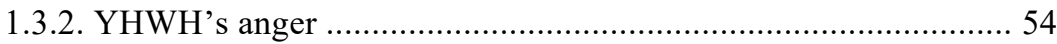

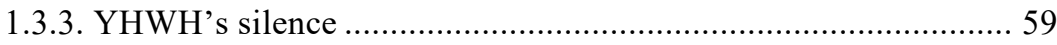

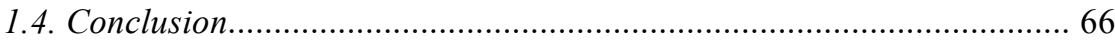

Chapter 2. Anticipating exile: Oracles of doom............................. 67

2.1. The destruction of Jerusalem and the exile in the Old Testament.......... 67 
2.1.1. Destruction and exile narrated and interpreted............................. 68

2.1.2. Destruction and exile anticipated................................................ 70

2.2. Exile and vast emptiness (Isaiah 6:1-13)............................................. 74

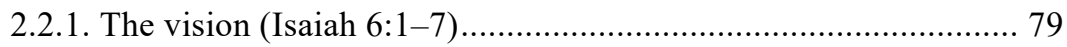

2.2.1.1. Isaiah 6:1-7: Text and translation ................................... 79

2.2.1.2. Isaiah $6: 1-4$ : The sovereign judge …………................. 80

2.2.1.3. Isaiah 6:5-7: The prophet's reaction and cleansing......... 82

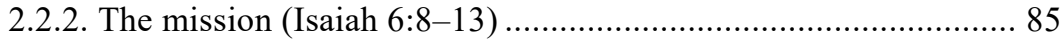

2.2.2.1. Isaiah 6:8-13: Text and translation ................................. 86

2.2.2.2. Isaiah 6:8-10: The sending of the prophet and

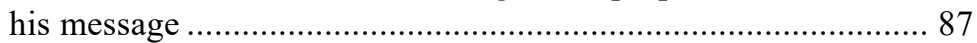

2.2.2.3. Isaiah 6:11-13: Deportation and complete destruction.... 91

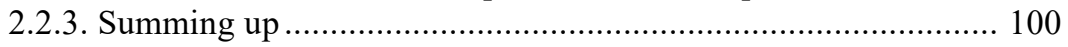

2.3. Jerusalem is doomed (Isaiah 22:1-14) ............................................ 100

2.3.1. Isaiah 22:1-14: Text and translation........................................ 104

2.3.2. Isaiah 22:1-4: The besieged Jerusalem and

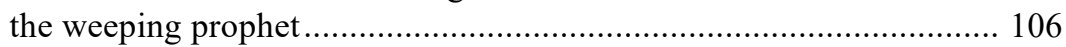

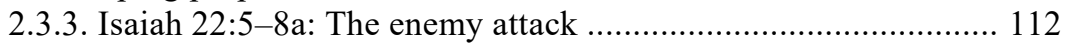

2.3.4. Isaiah 22:8b-11: Defense rather than faith ............................... 116

2.3.5. Isaiah 22:12-13: Festival rather than fasting ........................... 118

2.3.6. Isaiah 22:14: Death without forgiveness .................................. 119

2.3.7. Summing up ................................................................... 121

2.4. Everything shall be carried off to Babylon (Isaiah 39:1-8) ................ 121

2.4.1. Isaiah 39:1-8: Text and translation.......................................... 125

2.4.2. Isaiah 39:1-2: The visit from Babylon ..................................... 127

2.4.3. Isaiah 39:3-4: The prophet's interview ................................... 129

2.4.4. Isaiah 39:5-8: The prophetic word of doom .............................. 131

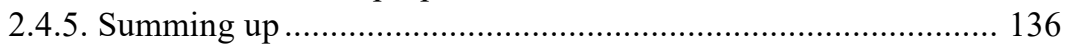

2.5. Zion has become a wilderness (Isaiah 63:7-64:11) .......................... 136

2.5.1. Review of history and the confession of $\sin . . . \ldots \ldots \ldots \ldots \ldots \ldots \ldots \ldots \ldots . . . . . . . . . . . . .140$

2.5.2. Isaiah 63:17-19a: Enemies took control of the people's land .... 142

2.5.3. Isaiah 64:7-11: Fire has destroyed the temple .......................... 147

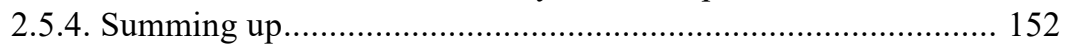

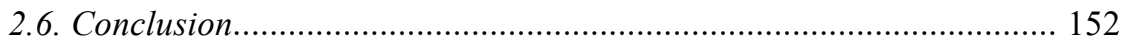


Chapter 3. Embodying exile: Typological figures 154

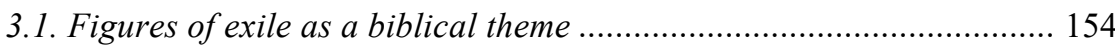

3.1.1. Excurses on the figures of Cain and Jonah .............................. 155

3.1.1.1. Driven away from the land (Cain)................................ 155

3.1.1.2. Down into the deep of the sea (Jonah) .......................... 159

3.2. The naked prophet (Isaiah 20:1-6) .................................................. 165

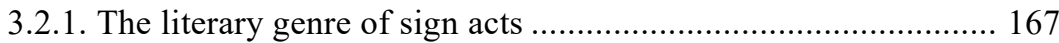

3.2.2. Isaiah 20:1-6: Text and translation......................................... 170

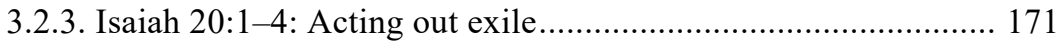

3.2.4. Isaiah 20:5-6: Consequences for the audience........................... 175

3.2.5. Excurses on other prophetic sign acts about exile...................... 178

3.2.5.1. Jeremiah's isolation (Jeremiah 16:1-13) ...................... 178

3.2.5.2. Ezekiel's departure from his house

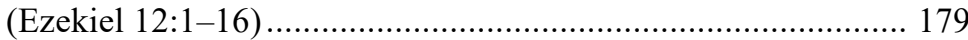

3.2.5.3. Nebuchadnezzar's capture of Egypt

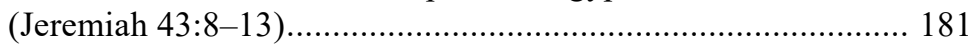

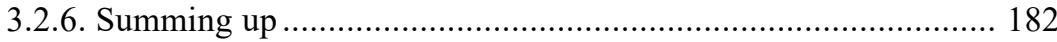

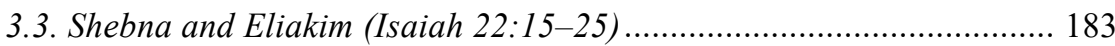

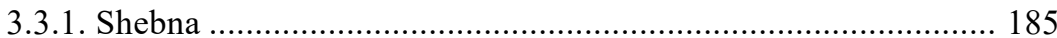

3.3.1.1. Isaiah 22:15-19: Text and translation .......................... 185

3.3.1.2. Isaiah 22:15-16: Shebna's transgression....................... 186

3.3.1.3. Isaiah 22:17-19: The punishment of exile and death..... 188

3.3.1.4. Excurses on parallel stories of exiled individuals.......... 191

3.3.1.4.1. Amaziah (Amos 7:10-17) ............................. 191

3.3.1.4.2. Pashur (Jeremiah 20:1-6)........................... 192

3.3.1.4.3. Jehoiachin (Jeremiah 22:24-30;

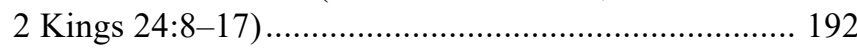

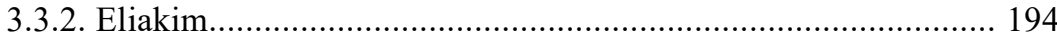

3.3.2.1. Isaiah 22:20-25: Text and translation .......................... 194

3.3.2.2. Isaiah 22:20-25: The call and fall of Eliakim ............... 195

3.3.3. Shebna and Eliakim as types for Judean kings.......................... 197

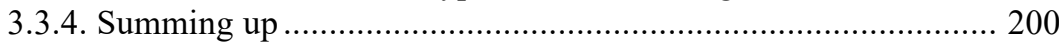

3.4. Hezekiah (Isaiah 38:1-22)............................................................. 200

3.4.1. Previous studies on exilic imagery in Isaiah 38 ....................... 201

3.4.2. The narrative and psalm in Isaiah 38 ..................................... 205

3.4.2.1. Differences between 2 Kings 20:1-11 and Isaiah 38.... 205

3.4.2.2. Interaction between narrative and psalm in Isaiah $38 \ldots .207$

3.4.3. Isaiah 38:1-8: Narrative frame ................................................. 209 
3.4.4. Isaiah 38:9-20: The psalm of Hezekiah................................... 211

3.4.4.1. The textual form of the psalm ...................................... 211

3.4.4.2. Isaiah 38:9-20: Text and translation .............................. 211

3.4.4.3. The literary form and structure of the psalm ................. 213

3.4.4.4. Isaiah 38:9: The heading............................................. 214

3.4.4.5. Isaiah 38:10-12a: Removal and isolation...................... 214

3.4.4.6. Isaiah 38:12b-14: Destruction and complaint ............... 222

3.4.4.7. Isaiah 38:15-17a: Judgment and restlessness ................ 225

3.4.4.8. Isaiah 38:17b-20: Anticipation of salvation.................. 228

3.4.5. Isaiah 38:21-22: Narrative frame .............................................. 231

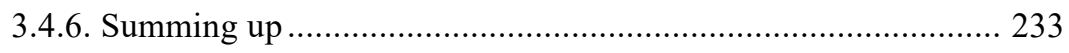

3.5. The suffering servant (Isaiah 52:13-53:12) .................................... 234

3.5.1. Literary motifs of exile in the servant portrait .......................... 235

3.5.1.1. Isaiah 53:7-9: The servant's deportation and grave ...... 236

3.5.2. Attempts to identify the figure in the context of exile................ 241

3.5.2.1. King Jehoiachin in Babylonian captivity ..................... 242

3.5.2.2. The people of Israel in exile ........................................ 244

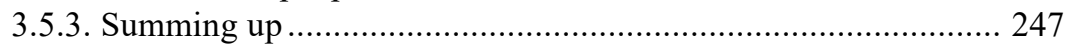

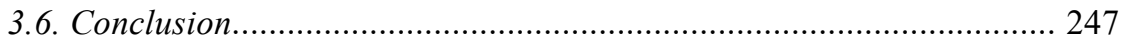

Chapter 4. Slavery and captivity: Political and spatial images. 249

4.1. A voice breaking the gap of silence (Isaiah 40:1-2) ........................ 250

4.1.1. Isaiah 40:1-2: Text and translation.......................................... 252

4.1.2. Isaiah 40:1-2: Heavenly comfort replaces heavy punishment.... 253

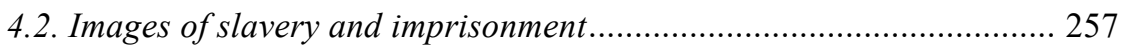

4.2.1. Isaiah 14:1-4a: Slaves become masters ................................... 258

4.2.2. Isaiah 42:6b-7: Liberating prisoners from dark dungeons ......... 263

4.2.3. Isaiah 42:22: A people robbed and trapped in holes .................. 266

4.2.4. Isaiah 51:13b-14: Fear of the oppressive tyrant ....................... 270

4.2.5. Isaiah $52: 1-6$ : The bond of slavery shall be loosened............... 273

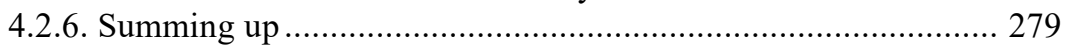

4.3. The redemptive power of YHWH.................................................... 279

4.3.1. Isaiah 43:1-4: Redemption through ransom ............................. 281

4.3.2. Isaiah 43:14-21: A way out of confinement .............................. 284

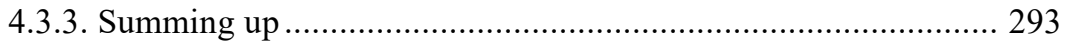

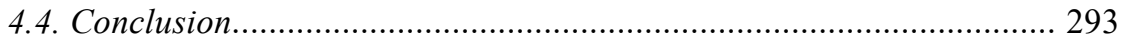


Chapter 5. Scattering and dispersion: Geographical images..... 295

5.1. The motif of scattering in the Old Testament ................................... 296

5.2. Gathering and reunifying the scattered people (Isaiah 11:11-16) ...... 301

5.2.1. Isaiah 11:11-16: Text and translation......................................... 302

5.2.2. Isaiah 11:11-12: Redemption and gathering of the dispersed .... 303

5.2.3. Isaiah 11:13-14: Reunification and reconquest ........................ 306

5.2.4. Isaiah 11:15-16: Splitting the river into streams........................ 307

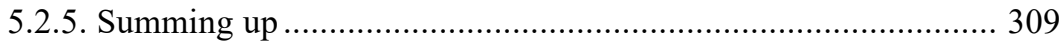

5.3. The great shofar shall sound (Isaiah 27:7-13) ................................ 309

5.3.1. Isaiah 27:7-13: Text and translation........................................ 312

5.3.2. Isaiah 27:7: Did Israel cease to exist?..................................... 314

5.3.3. Isaiah 27:8-9: Blast away by the wind .................................. 315

5.3.4. Isaiah 27:12-13: Gathering the harvest ................................. 320

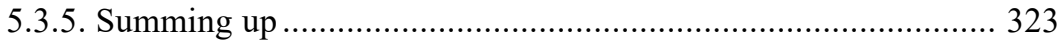

5.4. YHWH's gathering of his dispersed flock ........................................ 324

5.4.1. Isaiah 40:10-11: The divine warrior and shepherd ................... 324

5.4.2. Isaiah 43:5-7: Brought home from far away.............................. 327

5.4.3. Isaiah 49:9b-12: The returning flock......................................... 331

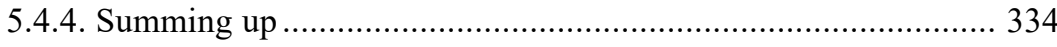

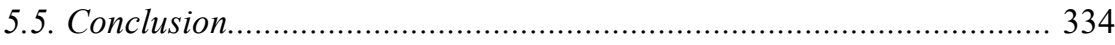

Chapter 6. Blindness and disorientation: Cognitive images...... 336

6.1. Knowledge and ignorance in the Old Testament ............................. 338

6.1.1. Wisdom-like language in Isaiah ............................................... 341

6.2. The blind and deaf people (Isaiah 42:18-25) .................................... 344

6.2.1. Isaiah 42:18-25: Text and translation..................................... 344

6.2.2. Isaiah 42:18-20: The blind and deaf servant ........................... 345

6.2.3. Isaiah 42:21-25: Understanding the past ................................. 349

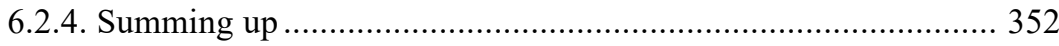

6.3. A stubborn and idolatrous people (Isaiah 48:1-8) ............................. 353

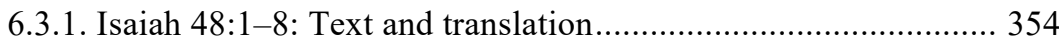

6.3.2. Isaiah 48:1-5: Past events announced beforehand .................... 354

6.3.3. Isaiah 48:6-8: The creation of new events............................... 358

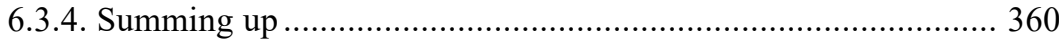


6.4. A people that walk in their own ways................................................ 361

6.5. A vision of renewed divine guidance .................................................. 365

6.6. The transformation of the hardened minds (Isaiah 41:17-20) ............ 368

6.6.1. Isaiah 41:17-20: Text and translation........................................ 369

6.6.2. Isaiah 41:17: The needy seeking wisdom ................................ 370

6.6.3. Isaiah 41:18-19: Transforming the wilderness ......................... 372

6.6.4. Isaiah 41:20: A complete understanding of YHWH's acts......... 375

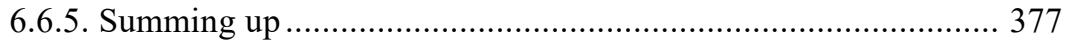

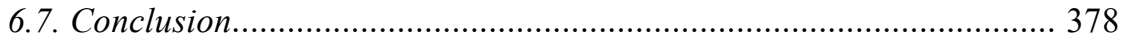

Chapter 7. Abandonment and bereavement: Social images ...... 379

7.1. Female imagery and issues of destruction and exile ........................ 380

7.1.1. The lonely woman in Lamentations.......................................... 382

7.1.2. Zion as a woman in Isaiah and the abasement of Lady Babylon 384

7.2. The children of Zion shall return to their mother (Isaiah 49:14-21)... 388

7.2.1. Isaiah 49:14-21: Text and translation...................................... 389

7.2.2. Isaiah 49:14-16: God's continuous attention to Zion................. 390

7.2.3. Isaiah 49:17-21: Restoration and repopulation of

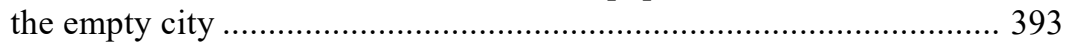

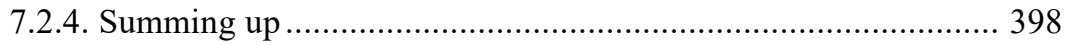

7.3. The barren mother shall conceive (Isaiah 54:1-6)........................... 398

7.3.1. Isaiah 54:1-6: Text and translation........................................... 400

7.3.2. Isaiah 54:1-3: A mother giving birth to innumerable children... 401

7.3.3. Isaiah 54:4-6: A forsaken and rejected wife is called back........ 405

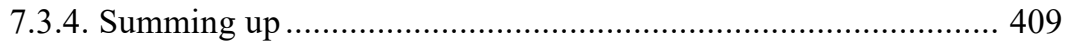

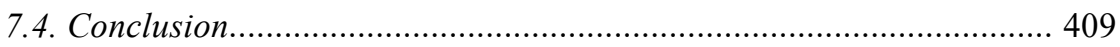

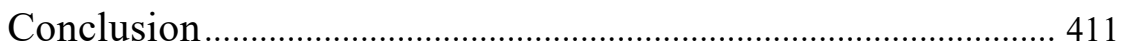

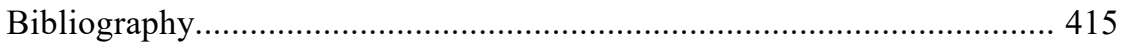

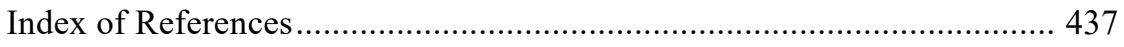

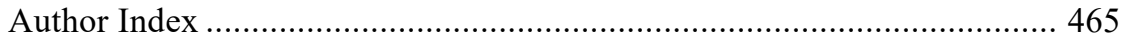

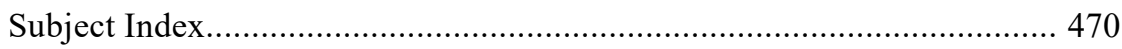




\section{Introduction}

Any study of exile in the book of Isaiah has to consider a peculiar contradiction. On the one hand, exile appears to be a central theme in the book; on the other, it is difficult to detect references to it. Francis Landy cogently writes: "Isaiah is all about exile - but in a way it is not about exile at all." While other biblical writings explicitly depict the destruction of Jerusalem and the people's deportation to Babylon in the early sixth century BCE, Isaiah is apparently silent. At the center of the book where readers would expect to find an account of these traumatic and defining events, there is just an abrupt break and a clear leap in time. Isaiah 39, which concerns the prophet's encounter with King Hezekiah in the end of the eighth century BCE, predicts the fall of Jerusalem and its captivity to Babylon. The following vision in Isa 40 , which seems to reflect a situation at least 160 years later, happily proclaims the end of exile and hope for future restoration. Yet the intermediate period - the exile itself - is not mentioned at all.

Why this apparent absence? Hugh Williamson states: "Exile is certainly not characteristic of Isaiah himself." Although the statement concerns the historical prophet living in the eighth century, it could be seen to cover most of the scholarly engagement with the book as a whole. Isaiah is thought to be about something else. Pervasive themes in the prophetic corpus include YHWH's protection and glorification of Zion, divine kingship, the issue of justice and righteousness, the inclusion of nations into the salvific realm, and the role of human agents such as the Messiah and the servant. However, even when the theme of exile is concerned, the primary focus lies on Isaiah's proclamation of release and restoration from it. To many interpreters, so it seems, experiences of exile may historically have shaped the composition and editorial reworking of several passages in Isaiah, especially those found in Isa 40-55, but the book as a whole is about something else. Exile itself simply disappears in the break between Isa 39 and 40.

The thesis of the present monograph is that exile in Isaiah hides itself as a "black hole" at the center of the composition and thereby has a decisive influence on the literary structure, poetic imagery, and theological message of the book. The gap between Isa 39 and 40 is like a black hole in space that, by its

\footnotetext{
${ }^{1}$ Landy, "Exile," 241.

${ }^{2}$ Williamson, Isaiah 1-5, 368.
} 
tremendous gravity, pulls everything to itself. Even light cannot escape from it. As a result, one can only study a black hole by looking at its effects on the surroundings. In a similar manner, exile conceals itself at the center of the prophetic book. Apparently, nothing happens - there is just a blank space but something decisive must take place. Exile is such a strong force that it absorbs life, light, and hope and only causes silence, darkness, and death. Therefore, one can only study exile in Isaiah by analyzing events and anticipations leading up to it and subsequent effects and reflections of it.

As the first comprehensive treatment, this monograph investigates exile as a literary and theological theme in Isaiah. The following introduction provides an overview of recent approaches to the study of exile in the Old Testament and a review of past scholarly works on this topic in Isaiah to situate the present investigation within the larger field of studies. Then, I offer some methodological considerations and sketch the overall structure of the monograph.

\section{Approaches to the study of exile}

Until the late $1960 \mathrm{~s}$, the exile - commonly understood to be the Babylonian exile (587-538 BCE) - was largely seen as a time of degeneration in the development of Israelite/Jewish religion. ${ }^{3}$ Julius Wellhausen, for instance, regarded the effects of the exile to be very negative and damaging, introducing an unconstructive period of priestly and legalistic thought. An important challenge to this dominating view, however, was Peter R. Ackroyd's book Exile and Restoration (1968) and its thesis that the sixth century was a dynamic and creative age for the formation and editorial shaping of much of the Old Testament literature. ${ }^{4}$ Since the 1980 s, a significant shift has occurred and in recent biblical scholarship the exile is studied not only as a historical event or period, but also as a broader social and cultural phenomenon. Three general approaches to the critical study of exile in biblical literature have emerged: historical-archeological, sociological, and literary. ${ }^{5}$

\footnotetext{
${ }^{3}$ See the informative reviews of scholarship in Ahn, Forced Migrations, 8-27; Kelle, "Interdisciplinary Approach."

${ }^{4}$ Ackroyd, Exile and Restoration.

${ }^{5}$ Cf. Ahn, "Exile," 197, and the headings for grouping essays in Ahn and Middlemas, By the Irrigation Canals of Babylon. A fourth approach would be the reception-historical study of the interpretation of exile in later Jewish and Christian writings. Seminal works in this connection are Michael A. Knibb's article "The Exile in the Literature of the Intertestamental Period" (1976) and the collection of essays in Exile: Old Testament, Jewish, and Christian Conceptions (1997) edited by James M. Scott. Works that are more recent include the co-authored book From Babylon to Eternity: The Exile Remembered and Constructed in Text and Tradition (2009) and the dictionary article "Exile" in Encyclopedia of
} 
The historical-archeological approach attempts to produce a critical and reliable reconstruction of the sixth century, centering on the Babylonian campaigns against Judah, the destruction of Jerusalem and deportation of its inhabitants, and the conditions for those who were deported and for those who remained in Judah. In addition to biblical texts, the examined material consists of archeological findings and Ancient Near Eastern sources and practices, including cuneiform texts from the Neo-Babylonian and Persian periods. ${ }^{6}$ Hans Barstad's The Myth of the Empty Land (1996) largely initiated a reassessment of the history and archeology of the period and was soon followed by the collection of papers in Leading Captivity Captive (1998) edited by Lester L. Grabbe. ${ }^{7}$ A major outcome of this reexamination has been a growing awareness of the discrepancy between the biblical picture of the exilic period and historical reconstructions of it. This is clear in two recent collections of articles: The Concept of Exile in Ancient Israel and its Historical Contexts (2010) edited by Ehud Ben Zvi and Christoph Levin and Myths of Exile: History and Metaphor in the Hebrew Bible (2015) edited by Anne Katrine de Hemmer Gudme and Ingrid Hjelm. ${ }^{8}$ Both volumes stress the literary creativity of biblical authors in their representations of the exile and its effects. Moreover, whereas past scholarship tended to reduce the period to one homogenous monolithic experience, recent works have emphasized the manifold and diverse aspects of this century in Judean history. ${ }^{9}$ Attention has been drawn to the fact that there were three different instances of deportation in the early sixth century $(597,587$, and 582 BCE) which should not be conflated and which deserve equal treatment. Furthermore, Judean communities not only existed in Babylon and Judah, but also in Assyria (following King Shalmaneser's capture of the Northern Kingdom in 722 BCE), Egypt, and several other places.

The sociological approach draws on methodologies and insights from social-scientific disciplines and studies exile as a broader cultural phenomenon

the Bible and its Reception (2014). Furthermore, Jörn Kiefer's Exil und Diaspora: Begrifflichkeit und Deutungen im antiken Judentum und in der hebräischen Bibel (2005) offers a dense lexicographical study of exilic terminology in the Bible and its reception in antique sources.

${ }^{6}$ See Lipschits and Blenkinsopp, Neo-Babylonian Period; Lipschits, The Fall and Rise of Jerusalem; Stökl and Waerzeggers, Exile and Return.

${ }^{7}$ Barstad, The Myth of the Empty Land; Grabbe, Leading Captivity Captive.

${ }^{8}$ Ben Zvi and Levin, Concept of Exile; Gudme and Hjelm, Myths of Exile, 1-4. See also the four essays devoted to historical issues in Ahn and Middlemas, By the Irrigation Canals of Babylon, 9-62.

${ }^{9}$ Ahn, Forced Migrations, 27-34; cf. Gudme and Hjelm, Myths of Exile, 4: "There is not one Exile in the Hebrew Bible, there are many, and there is not one interpretation of or portrayal of Exile in the biblical texts, there are as many as there are biblical authors sometimes even more." 
across time. The approach is interdisciplinary in nature as it seeks to place the biblical texts in close dialogue with sociological, anthropological, and psychological analysis. This is often done by comparing the experiences of exile reflected in the Bible to contemporary experiences, patterns, and social realities, informed by various modern sub-disciplines such as disaster studies, refugee studies, and trauma theory. A pioneer in this approach is Daniel L. Smith-Christopher. His groundbreaking book The Religion of the Landless: The Social Context of the Babylonian Exile (1989) applies sociological methodology to the study of the exilic period and its literature, and his A Biblical Theology of Exile (2002) relates this concern to larger ethical and theological issues. ${ }^{10}$ A scholar who has followed in these footsteps is John J. Ahn. His Exile as Forced Migrations (2011) studies the social structures of forced migration. ${ }^{11}$ Drawing extensively on contemporary theories of migrations, economics, and generation issues among refugees, he seeks to understand the distinct waves of forced migrations in the sixth century and the exilic experience and identity formation of each successive generation of Judeans living in Babylon. Several essays in the recent volume Interpreting Exile: Displacement and Deportation in Biblical and Modern Contexts (2012) edited by Brad E. Kelle, Frank Ritschel Ames, and Jacob L. Wright likewise examine the biblical experiences in conjunction with the general phenomenon of exile. ${ }^{12}$ The volume incorporates broader cross-disciplinary perspectives and offers a series of case studies which compare the stories of migration in the Bible with those of modern refugee crises and diaspora communities.

The literary approach focuses on the textual representations and expressions of exile in the Bible. The object of study is the literary responses to the exile and its impacts on the poetic and theological reflection of biblical authors. Initially, it is striking to notice that separate books and passages speak very differently about exile and employ a whole range of literary genres, including historiography, laments, hymns, and prophecy. As was mentioned, Peter R. Ackroyd's Exile and Restoration (1968) stresses the literary activity and creativity of the exilic period. He concentrates on thoughts rather than events and seeks to trace patterns of reflection and religious development in the reactions to the exile and exilic situation by examining the various texts from this period, including Jeremiah, the Deuteronomistic History, the Priestly work, Ezekiel, Deutero-Isaiah, Haggai, Zechariah, and poetic passages.

${ }^{10}$ Smith, Religion of the Landless; Smith-Christopher, A Biblical Theology of Exile. See also his retrospective assessment of the development of the approach in Smith-Christopher, "Reading Exile Then."

${ }^{11}$ Ahn, Forced Migrations.

${ }^{12}$ Kelle, Ames, and Wright, Interpreting Exile. See also the four essays devoted to sociological issues in Ahn and Middlemas, By the Irrigation Canals of Babylon, 125-89. 
Not surprisingly, subsequent scholarly introductions to the literature of the period share this way of ordering and presenting the biblical material. ${ }^{13}$

Rainer Albertz's presentation of the history and literature of the sixth century in Israel in Exile (2003) likewise highlights the large-scale literary activity of this century: "Approximately half of the material in the Hebrew Bible came into being or was substantially shaped during this era." 14 The primary focus of this comprehensive introduction is a detailed examination of the genres and writings assigned to this period, including their literary reconstruction, their political and religious substance, and their socio-historical context. In contrast to Ackroyd's interest in the development of religious thought, Albertz pays more attention to literary issues of form, composition, and origin. In particular, he emphasizes the role of editorial activity in the formation and reworking of biblical literature.

With regard to literary representations of exile in biblical texts, Robert P. Carroll has written two important articles: "Deportation and Diasporic Discourses in the Prophetic Literature" (1997) and "Exile! What Exile? Deportation and the Discourses of Diaspora" (1998). ${ }^{15}$ While Ackroyd and Albertz stress the exilic period as a dynamic age for the production of literature, Carroll highlights the importance of exile as a literary motif in the biblical corpus as a whole: "The Hebrew Bible is the book of exile. It is constituted in and by narratives and discourses of expulsion, deportation and exile." ${ }^{16}$ In the former article, he offers an informative survey of the range of the discourses of deportation, destruction, and return in prophetic texts. ${ }^{17}$ In the latter article, he considers the relation between the biblical language of exile and the historical events that this language may reflect. Carroll writes:

${ }^{13}$ Ralph W. Klein's Israel in Exile (1979) examines six literary works - "six exilic voices" - and their responses to the theological challenges of exile: Lamentations and exilic psalms, the Deuteronomistic History, Jeremiah, Ezekiel, Second Isaiah, and P. More recently, Jill Middlemas' The Templeless Age (2007) introduces the biblical literature of the exilic century along thematic lines and types of reactions. They include: a lack of future vision (certain psalms, Isa 63:7-64:11, Lamentations, and the Deuteronomistic History), the intermingling of judgment and hope (Jeremiah and Ezekiel), and a turn to hope (Deutero-Isaiah, Ezek 40-48, Haggai, Zech 1-8, and the Holiness Code).

${ }^{14}$ Albertz, Israel in Exile, ix. The original German version appeared two years earlier (Die Exilszeit: 6. Jahrhundert v. Chr.) in Kohlhammer's Biblische Enzyklopädie series.

${ }^{15}$ Carroll, "Deportation"; "Exile."

${ }^{16}$ Carroll, "Deportation," 64; cf. "Exile," 63: "Exile and exodus: those are the two sides or faces of the myth that shapes the subtext of the narratives and rhetoric of the Hebrew Bible. Between these twin topoi (and their mediating notion of the empty land) is framed, constructed and constituted the essential story of the Hebrew Bible."

${ }^{17}$ Recent surveys of the rhetoric of exile in the prophets include David L. Petersen's "Prophetic Rhetoric and Exile" (2015) and Cian Power's "Constructions of Exile in the Persian Period" (2015) and "Images of Northern Exile” (2019). 
Exile is a biblical trope and, whether it may be treated as an event in the real socioeconomic historical world outside the text or not, it should be treated as a fundamental element in the cultural poetics of biblical discourses. It may have historical referents, but it is as a root metaphor that it contributes most to the biblical narrative. ${ }^{18}$

The main point is that the biblical representations of exile do not need to relate to history at all. The employed tropes may reflect historical events, but they do not have to. In several cases, it is difficult to determine whether we encounter reflections of real experiences or imaginative constructs. ${ }^{19}$

John Kessler's article "Images of Exile" (2010) provides a highly informative overview of literary representations of "exile" and "empty land" in the sixth to fourth century literature. ${ }^{20}$ Attention is drawn to the centrality of these motifs in biblical literature and the different form and function of them in various writings from the period. ${ }^{21}$ Martien A. Halvorson-Taylor's Enduring Exile: The Metaphorization of the Exile in the Hebrew Bible (2011) studies the transformation of exile from geographical dislocation to a symbol of a variety of alienations, including political disenfranchisement and an existential alienation from God. ${ }^{22}$ She analyzes in depth the use of metaphors for exile in a series of passages from Jer 30-31, Isa 40-66, and Zech 1-8. Samuel Balentine's article "The Prose and Poetry of Exile" (2012) offers insightful considerations on the significance of various genres for mourning and recording the suffering of exile. ${ }^{23}$

With regard to the prophetic literature, two recent collections of papers are of relevance. The first one is The Prophets Speak on Forced Migration (2015) edited by Mark J. Boda, Frank Ritchel Ames, John Ahn, and Mark Leuchter. ${ }^{24}$ The volume draws attention to the recurrent motif of exile-forced migration in Old Testament prophecy. The second is the volume Images of Exile in the Prophetic Literature (2019) edited by Jesper Høgenhaven, Cian

${ }^{18}$ Carroll, "Exile," 64.

${ }^{19} \mathrm{Cf}$. Gudme and Hjelm, Myths of Exile, 3-4: "the theme of exile in the Hebrew Bible should not only be viewed as an echo of traumatic historical events, but also as a literary theme that is taken up and reworked in a variety of ways by the biblical authors in order to build specific identities and to express ideology."

${ }^{20}$ Kessler, "Images of Exile."

${ }^{21}$ Kessler ("Images of Exile," 315-47) groups the examined texts in seven sections: 1. Texts favoring the 597 exiles (Jer 24; Ezek 11:14-21); 2. Inclusion of all the Babylonian exiles (Ezek 33:21-29); 3. Exclusion of the Egyptian Diaspora (Jer 40:7-41:18; 42:1-22; $43: 1-13 ; 44: 1-30) ; 4$. Full emptying of the land as a result of Israel's disobedience (Lev 26:14-45; Deut 28:15-68); 5. The Babylonian golah as the sole repository of authentic Yahwism (2 Kings 25:22-26; Ezra-Nehemiah); 6. Full return of those scattered in Yahweh's judgment (Zech 1-8, Isaiah, Micah); and 7. No exile and no empty land (Haggai).

${ }^{22}$ Halvorson-Taylor, Enduring Exile.

${ }^{23}$ Balentine, "Prose and Poetry."

${ }^{24}$ Boda, Ames, Ahn and Leuchter, Prophets. 
Power, and myself. ${ }^{25}$ Several of the essays reflect on the language and metaphors that the prophets use to express the experience of exile.

\section{Recent studies of exile in Isaiah}

Two main factors have shaped past scholarship on exile in Isaiah. First, an important drawback of Bernhard Duhm's division of the book into three major sections (Isa 1-39, 40-55, and 56-66) was that scholars have approached these sections in almost complete isolation from one another as if they are independent prophetic books. This division has implied that the study of exile in Isaiah throughout the twentieth century in practice has focused on Isa 4055 alone. A common assumption has been that these chapters should be assigned to an anonymous sixth-century author - "the Great Prophet of the Exile" - who lived among the Judean exiles in Babylon and addressed their needs. ${ }^{26}$ Second, the frequent observation that Isa $40-55$ from the very outset looks back on the exile as something that is now over has made scholars concentrate on the proclamation of hope and restoration rather than on the experience of exile itself. ${ }^{27}$ With regard to exile, several of the works on Isa 40-55 are systematic presentations of the alleged response of this prophet to the theological problems of the exilic period. ${ }^{28}$

An illustrative example is Peter R. Ackroyd's treatment of Isaiah in Exile and Restoration (1968) which because of its interest in the literature of the sixth century limits itself to Isa $40-55 .{ }^{29} \mathrm{He}$ locates the prophetic author in Babylon and looks for those features in the chapters that illuminate the exilic

\footnotetext{
${ }^{25}$ Høgenhaven, Poulsen and Power, Images of Exile.

${ }^{26}$ For an excellent overview, see Tiemeyer, Comfort, 13-51. Cf. also the recent essay "Provenance as a Factor in Interpretation" (2015) by Christopher R. Seitz in which he discusses the role of setting (historical reconstructions vs. canonical context) for reading Isa 40-55.

${ }^{27}$ Cf. Albertz, Israel in Exile, 380: "the book of Deutero-Isaiah is the only prophetic book of the exilic period that contains nothing but prophecy of salvation."

${ }^{28}$ For instance, Ralph Klein (Israel in Exile, 97-124) interprets Isa $40-55$ as one long response to the exiled people's doubts about YHWH's ability and willingness to save: "the author sang his message into the dark night of Israel's exile." Jill Middlemas (The Templeless Age, 94-111) also emphasizes the jubilant message that YHWH is acting salvifically in the midst of the exiles. In her opinion, Isa 40-55 has two goals: to stir the exiled community to leave Babylon and to comfort the despairing people. Rainer Albertz (Israel in Exile, 376-433) offers a rather technical examination of the historical development of the literary composition of Isa 40-55, proposing two editions, each of which has a distinctive theological message.

${ }^{29}$ Ackroyd, Exile and Restoration, 118-37. Three pages in a subsequent chapter deal with selected texts from Isa 56-66 under the heading "Passages reflecting restoration"; see Exile and Restoration, 228-30.
} 
situation. In his presentation, Ackroyd initially makes a division between "the backward and forward looking of the prophet," that is, between the understanding of disaster and the prospect of salvation. ${ }^{30}$ The first section - "The people's present condition" - examines the exile as YHWH's punishment of his people because of sin, thereby drawing more attention to their depressing condition in Isa 40-55 than other interpreters are perhaps willing to. ${ }^{31}$ The people themselves are seen to be wholly responsible for their present condition of humiliation: "The exile is at one and the same time a proper punishment for what Israel has been in the past and an act of discipline by which the future may be assured." 32 The second section - "The future hope" - then presents the various images of redemption in Isa 40-55, including the release from captivity, the exodus-like return, and the complete restoration of the land by means of YHWH's creative power. All of these ideals are expressions of hope formulated against the background of exile.

While Exile and Restoration limits itself to Isa 40-55, Peter Ackroyd has dealt with passages in Isa 1-39 in later works. ${ }^{33}$ His article "An Interpretation of the Babylonian Exile" (1974) in particular is an excellent identification of literary motifs of exile in Isa 38-39 (cf. 2 Kings 20) and contains an informative discussion of the purpose of these chapters within the overall composition of Isaiah. ${ }^{34}$

As far as I am aware, the recent rediscovery of the unity of Isaiah has not yet resulted in elaborate examinations of the theme of exile in the prophetic composition as a whole. Nevertheless, one can find briefer treatments of this issue in some of the works referred to in the previous section. The opening of Robert P. Carroll's four-page review (1997) ${ }^{35}$ highlights the importance of the motif:

Isaiah is the great scroll of diaspora discourses in the prophetic collection in the Hebrew Bible. It is shot through with images of devastation and deportation, of fugitives driven from their homeland and of abandoned territory which testifies to a disrupted cultivation, with loss of the civic centre. ${ }^{36}$

\footnotetext{
${ }^{30}$ Ackroyd, Exile and Restoration, 121: "Here we may distinguish, in spite of obvious interrelationship, between the prophet's understanding of how his people has come to be where it is, and the anticipation which he shows of events in which God is acting and will continue to act to effect his purposes."

${ }^{31}$ Cf. the criticism in Middlemas, The Templeless Age, 102.

${ }^{32}$ Ackroyd, Exile and Restoration, 126.

${ }^{33}$ Ackroyd, Studies.

${ }^{34}$ The article was originally published in Scottish Journal of Theology; see Ackroyd, Studies, 152-71.

${ }^{35}$ Carroll, "Deportation," 73-77.

${ }^{36}$ Carroll, "Deportation," 73.
} 
Among others, he observes that the notion of the great return of the dispersed ones (e.g. 14:1-2;19:18-25;27:12-13;43:5-6;49:12) and the flow of nations to Jerusalem (e.g. $2: 1-4 ; 66: 12,18)$ are pervasive themes in the book as a whole, contributing to its diasporic discourses: "the scroll itself represents a magnificent panorama of alienation, deportation and homecoming." 37

John Kessler's three-page review (2010) ${ }^{38}$ likewise observes that "the motif of vast devastation followed by scattering and ultimately re-gathering of all Israel is [...] a highly important motif in the Isaianic corpus." ${ }^{39}$ As a test case, he examines Isa 6:1-11:16. Like bookends, Isa 6:11-13 and 11:11-16 "introduce and then resolve the matter of the exile and empty land in the section." ${ }^{40}$ Kessler draws attention to an important feature which forms a contrast to other biblical accounts of the exile. In Isaiah, there is no favored or excluded group. The basic polarity is not between various groups within the people (e.g. those who were exiled and those who remained in the land), but between the prophet as YHWH's messenger and the population in toto: "The people of God consist of all the descendants of Israel [...] All have disobeyed and as a result judgment has come upon all." ${ }^{41} \mathrm{He}$ furthermore observes "the highly schematized vision" of these Isaianic texts. ${ }^{42}$ In Isaiah's vision, the complete devastation and forsakenness of the land balance its complete restoration and repopulation.

A series of recent studies on exile in Isaiah has engaged in shorter passages or sections. Bradley C. Gregory's article, "The Postexilic Exile in Third Isaiah" (2007), offers a reading of Isa 61:1-3 in light of Second Temple hermeneutics. ${ }^{43} \mathrm{He}$ attempts to demonstrate that this Isaianic passage is one of the earliest attestations to the concept of an enduring exile, that is, exile as an ongoing state beyond the geographical and temporal bounds of the Babylonian captivity. ${ }^{44}$

${ }^{37}$ Carroll, "Deportation," 76.

${ }^{38}$ Kessler, "Images of Exile," 341-44.

${ }^{39}$ Kessler, "Images of Exile," 341. As examples of texts, he lists Isa 6:11-13; 11:11, 16; $14: 2 ; 43: 1-7 ; 44: 24-28 ; 45: 12-13 ; 48: 20-21 ; 49: 19-26 ; 51: 9-11 ; 60: 1-22 ; 62: 1-8 ; 66: 10$ 16.

${ }^{40}$ Kessler, "Images of Exile," 342.

${ }^{41}$ Kessler, "Images of Exile," 343.

${ }^{42}$ Kessler, "Images of Exile," 343: "There is no distinction between various groups of Yahwists based upon their geographical location, their redemptive sufferings, or their fate during the period of Yahweh's judgment upon the land. Neither is there any explicit mention of their repentance or responsiveness to Yahweh."

${ }^{43}$ Gregory, "Postexilic Exile."

${ }^{44}$ See also the essay "The Individualization of Exile in Trito-Isaiah" (2019) by Ulrich Berges in which he explores how exile is turned into an individual and existential condition which can only be overcome by a certain ethical behavior. 
Fredrik Hägglund's dissertation Isaiah 53 in the Light of Homecoming after Exile (2008) aims at understanding what problem Isa 53 addresses and seeks to answer. ${ }^{45}$ He regards the specific historical problem behind this text to be a conflict regarding repatriation of the Judean exiles returning from Babylon in the late sixth century, because those who had remained in the land were reluctant to receive them. Isaiah 53, so he argues, encourages the people in the land to embrace the returnees as ones who have suffered on their behalf. Although Hägglund's main approach is historical, he applies a series of theories and methodologies in his investigation of the text of Isa 53, its notions of vicarious suffering and of exclusion and embrace, and its literary, geographical, and social contexts. Notably, in line with Smith-Christopher, Hägglund draws from modern refugee studies and the issues they present about the problems of homecoming in order to shed further light on the social conflict reflected in the biblical text. ${ }^{46}$

The application of a contemporary, sociological perspective to Isaiah is also present in Gregory Lee Cuéllar's monograph Voices of Marginality: Exile and Return in Second Isaiah 40-55 and the Mexican Immigrant Experience (2008). ${ }^{47} \mathrm{He}$ employs insights from postcolonial studies and diaspora theology. A central aim of the work is to compare the rhetoric of Isa 40-55 to the Mexican corrido ballad songs, a traditional type of folk song, the lyrics of which describe aspects of Mexican immigrant experiences in the United States. Cuéllar attempts to demonstrate that there are shared socio-political and socio-religious concerns between the corridos and Isa 40-55 and that both groups of texts share a series of themes (e.g. marginalization, longing for home, yearning to return). In his view, the biblical and Mexican experience can inform each other.

Finally, two recent works, both of which are of particular significance to my own study, are devoted to the literary character of exile in Isaiah. The first one is Francis Landy's essay "Exile in the Book of Isaiah" (2010) which offers some highly original and inspiring ideas about this issue in the prophetic composition as a whole. ${ }^{48}$ His essay is both thought-provoking and demanding. As cited at the beginning of the introduction, Landy initially observes an apparent contradiction. Exile is central to the structure and message of Isaiah, but it is very hard to find. On the one hand, all of the major sections of the book are concerned with exile. Isaiah 1-39 foreshadows the disaster of the early sixth century and the restoration from it by the fall of Samaria and the deliverance of Judah in the eighth century. The feeling of deep loss and

${ }^{45}$ Hägglund, Isaiah 53.

${ }^{46}$ Hägglund, Isaiah 53, 156-72.

${ }^{47}$ Cuéllar, Voices of Marginality.

${ }^{48}$ Landy, "Exile." His approach is advanced in the essay "Metaphors of Death and Exile in Isaiah" (2019). 


\section{Index of References}

\section{Old Testament}

\begin{tabular}{|c|c|c|c|}
\hline Genesis & & $11: 1-9$ & 296-97, 339 \\
\hline 1 & 52 & $11: 4$ & 296 \\
\hline $1-11$ & 296 & $11: 8$ & 296 \\
\hline $2-3$ & 218 & 11:9 & 296 \\
\hline $2: 7$ & 147 & $11: 27-12: 20$ & 155 \\
\hline $2: 9$ & 38 & $11: 30$ & 401 \\
\hline $2: 17$ & 38 & $12: 10$ & 278 \\
\hline $2: 25$ & 173 & $13: 9$ & 404 \\
\hline 3 & 157 & $13: 14-18$ & 131 \\
\hline $3: 3-4$ & 120 & $14: 19$ & 305 \\
\hline $3: 6$ & 376 & $14: 22$ & 305 \\
\hline $3: 7$ & 173 & $15: 18$ & 322 \\
\hline $3: 8$ & 268 & $19: 20$ & 145 \\
\hline $3: 10$ & 173,268 & $21: 14$ & 361 \\
\hline $3: 14$ & 156 & $25: 21$ & 401 \\
\hline $3: 16$ & 262 & $28: 14$ & $328,334,404$ \\
\hline $3: 17$ & 156 & $29: 31$ & 401 \\
\hline $3: 23$ & 316 & $31: 18$ & 174,333 \\
\hline $3: 24$ & 157,164 & $31: 26$ & 174 \\
\hline $4: 1-16$ & 155 & $31: 40$ & 226 \\
\hline $4: 9-16$ & 156 & $31: 50$ & 152 \\
\hline $4: 10-11$ & 157 & $32: 29$ & 282 \\
\hline $4: 11$ & $156-57$ & $33: 12$ & 220 \\
\hline $4: 11-12$ & $156-57$ & $33: 13$ & 325 \\
\hline $4: 12$ & $156-57,372$ & $33: 14$ & 333 \\
\hline \multirow[t]{2}{*}{$4: 14$} & $156-57,164,227$ & $34: 21$ & 189 \\
\hline & 372 & $34: 29$ & 267 \\
\hline $4: 16$ & 157,227 & $35: 7$ & 119 \\
\hline $5: 24$ & 239 & 37 & 269 \\
\hline $6: 19-20$ & 227 & $37: 26-28$ & 276 \\
\hline $7: 11$ & 289 & $37: 34$ & 172 \\
\hline $8: 21$ & 50,359 & $37: 35$ & 42 \\
\hline $9: 15$ & 50 & $37: 36$ & 132 \\
\hline $9: 19$ & 320 & $39: 22$ & 265 \\
\hline $9: 22$ & 173 & $41: 5-7$ & 321 \\
\hline $9: 22-23$ & 175 & $41: 6$ & 318 \\
\hline $10: 18$ & 297 & $41: 22-24$ & 321 \\
\hline
\end{tabular}




\begin{tabular}{|c|c|c|c|}
\hline $41: 26-27$ & 321 & $21: 30$ & 283 \\
\hline $42: 24$ & 110 & $22: 3$ & 256 \\
\hline $43: 31$ & 61,151 & $22: 6$ & 256 \\
\hline $45: 1$ & 61 & $22: 8$ & 256 \\
\hline $45: 8$ & 195 & $23: 10$ & 306 \\
\hline $48: 16$ & 280 & $25: 9$ & 188 \\
\hline $49: 7$ & 297 & $27: 19$ & 195 \\
\hline $50: 10$ & 118 & $28: 40$ & 195 \\
\hline $50: 20$ & 227 & $28: 42$ & 175 \\
\hline \multirow[t]{2}{*}{$50: 21$} & 254 & $30: 12$ & 283 \\
\hline & & $31: 3$ & 38 \\
\hline Exodus & & $32: 4$ & 356 \\
\hline $1: 11-14$ & 249 & $32: 8$ & 361 \\
\hline $1: 12$ & 404 & $33: 11$ & 197 \\
\hline $1: 14$ & 263 & $33: 20$ & 84 \\
\hline $2: 12$ & 362 & $34: 10$ & 359 \\
\hline $3-4$ & 76 & $34: 24$ & 107 \\
\hline $3: 1$ & 174,325 & $38: 8$ & 254 \\
\hline $3: 7$ & 262 & $38: 21$ & 216 \\
\hline $4: 10$ & 85 & & \\
\hline $4: 15$ & 85 & Leviticus & \\
\hline $4: 22-23$ & 140 & $1: 4$ & 255 \\
\hline $4: 23$ & 315 & $5: 21$ & 225 \\
\hline $5: 6$ & 262 & $5: 23$ & 225 \\
\hline $5: 10$ & 262 & 14 & 218 \\
\hline $5: 13-14$ & 262 & $16: 4$ & 189 \\
\hline $6: 6$ & 280 & 18 & 175 \\
\hline $6: 7$ & 375 & $19: 7$ & 255 \\
\hline $6: 9$ & 262 & $19: 9$ & 321 \\
\hline $7: 3$ & 143 & $19: 10$ & 321 \\
\hline $7: 23$ & 362 & 20 & 175 \\
\hline $10: 1$ & 89 & $21: 18$ & 308 \\
\hline $13: 3$ & 249 & $23: 22$ & 321 \\
\hline $13: 9$ & 303 & $25: 1-2$ & 72 \\
\hline $13: 14$ & 264 & $25: 1-7$ & 72 \\
\hline $14: 3$ & 112 & $25: 9$ & 322 \\
\hline $14: 16$ & 308 & $25: 23-34$ & 280 \\
\hline $14: 21$ & 289,308 & $25: 46$ & 260 \\
\hline $14: 26-27$ & 308 & $25: 47-66$ & 280 \\
\hline 15 & 292 & $25: 50$ & 254 \\
\hline $15: 2$ & 213 & 26 & $68,71-74,94-95$ \\
\hline $15: 3$ & 60 & $26: 1-2$ & 71 \\
\hline $15: 8-10$ & 308 & $26: 3-13$ & 72 \\
\hline $15: 13$ & 280,333 & $26: 14-26$ & 72 \\
\hline $15: 16$ & $82,303,305$ & $26: 14-45$ & 6 \\
\hline $15: 22$ & 220 & $26: 21$ & 314 \\
\hline $17: 1-7$ & 372 & $26: 27-45$ & 72 \\
\hline $21: 1-11$ & 277 & $26: 31$ & 96 \\
\hline $21: 2$ & 304 & $26: 31-33$ & 94 \\
\hline
\end{tabular}




\begin{tabular}{|c|c|c|c|}
\hline $26: 33$ & 299 & $22: 19$ & 316 \\
\hline $26: 34-45$ & 255 & $24: 1$ & 392 \\
\hline $26: 43$ & $97,255,408$ & $24: 1-3$ & 316 \\
\hline $26: 46$ & 72 & $24: 20$ & 321 \\
\hline \multirow[t]{2}{*}{$27: 30-33$} & 97 & $26: 12-15$ & 97 \\
\hline & & 28 & $68,71-73,94-95$ \\
\hline Numbers & & $28: 1$ & 71 \\
\hline $1: 3$ & 254 & $28: 1-14$ & 73 \\
\hline $4: 23$ & 254 & $28: 3-14$ & 73 \\
\hline $8: 24-25$ & 254 & $28: 7$ & 94 \\
\hline $11: 12$ & 326 & $28: 10$ & 146 \\
\hline $16: 30$ & 41 & $28: 15-25$ & 73 \\
\hline $16: 32-33$ & $41-42$ & $28: 15-68$ & 6,73 \\
\hline $18: 21-24$ & 97 & $28: 21$ & 94 \\
\hline $20: 1-13$ & 372 & $28: 26-46$ & 73 \\
\hline $21: 6$ & 81 & $28: 37$ & 174,333 \\
\hline $22: 31$ & 116 & $28: 41$ & 249 \\
\hline $28: 7$ & 33 & $28: 47-57$ & 73 \\
\hline $31: 9$ & 267 & $28: 48$ & $40,276,332,371$ \\
\hline $33: 54$ & 260 & $28: 49$ & 130 \\
\hline $35: 19-27$ & 280 & $28: 53$ & 271 \\
\hline \multirow[t]{2}{*}{$35: 31-32$} & 283 & $28: 55$ & 271 \\
\hline & & $28: 57$ & 271 \\
\hline Deuteronomy & & $28: 58-61$ & 314 \\
\hline $2: 12$ & 146 & $28: 58-68$ & 73,353 \\
\hline $2: 30$ & 143 & $28: 63$ & 94 \\
\hline $3: 27-28$ & 131 & $28: 63-68$ & 218 \\
\hline $4: 6$ & 340,347 & $28: 64$ & $297-98$ \\
\hline $4: 9$ & $340,347,349$ & $28: 64-65$ & 383 \\
\hline $4: 25-31$ & 371 & $28: 65$ & 262 \\
\hline $4: 27$ & $174,297,333$ & $28: 65-66$ & 262 \\
\hline $4: 28-29$ & 371 & $28: 65-67$ & 74 \\
\hline $5: 15$ & 303 & $29: 1-3$ & 347 \\
\hline $6: 4-5$ & 89 & $29: 17$ & 362 \\
\hline $8: 2-3$ & 151 & $29: 22$ & 150 \\
\hline $8: 16$ & 151 & $30: 1-4$ & 300 \\
\hline $9: 1$ & 404 & $30: 3$ & 297 \\
\hline $10: 17$ & 60 & $30: 4$ & 301 \\
\hline $11: 23$ & 404 & $30: 15-20$ & 340 \\
\hline $12: 3$ & 320 & $30: 17$ & 299 \\
\hline $13: 6$ & 299 & $30: 17-18$ & 362 \\
\hline $14: 22-29$ & 97 & $31: 3$ & 404 \\
\hline $14: 26$ & 34 & $31: 17-18$ & 50 \\
\hline $15: 18$ & 256 & $31: 29$ & 56 \\
\hline $18: 14$ & 404 & $32: 1-4$ & 131 \\
\hline $19: 1$ & 404 & $32: 6$ & 147,305 \\
\hline $19: 6$ & 280 & $32: 9$ & 55 \\
\hline $20: 14$ & 267 & $32: 15$ & 90 \\
\hline $22: 1$ & 299 & $32: 20$ & 50 \\
\hline
\end{tabular}




\begin{tabular}{|c|c|c|c|}
\hline \multirow{3}{*}{$\begin{array}{l}32: 24 \\
32: 33\end{array}$} & 32 & $2: 5$ & 402 \\
\hline & 56 & $2: 6$ & 53 \\
\hline & & $2: 8$ & 275 \\
\hline \multicolumn{2}{|l|}{ Joshua } & $2: 22$ & 254 \\
\hline $1: 8$ & 224 & $9: 3$ & 323 \\
\hline $4: 3$ & 190 & $9: 15$ & 37 \\
\hline $4: 9$ & 190 & $9: 20$ & 323 \\
\hline $6: 10$ & 60 & $11: 8$ & 97 \\
\hline $6: 16$ & 60 & $11: 11$ & 297 \\
\hline $7: 1$ & 188 & $12: 3$ & 283 \\
\hline $7: 2-26$ & 188 & $13: 6$ & 268 \\
\hline $10: 12-13$ & 206 & $13: 11$ & 320 \\
\hline \multirow[t]{2}{*}{$11: 14$} & 267 & $13: 12$ & 61 \\
\hline & & $14: 1$ & 190 \\
\hline \multicolumn{2}{|l|}{ Judges } & $14: 11$ & 268 \\
\hline $1: 16$ & 158 & $17: 20$ & 60 \\
\hline $2: 14$ & 267 & $18: 11$ & 188 \\
\hline $4: 11$ & 158 & $20: 33$ & 188 \\
\hline $4: 17$ & 158 & $23: 5$ & 174 \\
\hline $4: 21-22$ & 195 & $28: 17$ & 172 \\
\hline $5: 4$ & 63 & $30: 2$ & 174 \\
\hline $6: 11$ & 320 & $30: 2-3$ & 261 \\
\hline $6: 11-17$ & 76 & $30: 20$ & 174 \\
\hline $6: 18$ & 197 & & \\
\hline $6: 25$ & 190 & 2 Samuel & \\
\hline $13: 2-3$ & 401 & $6: 12$ & 232 \\
\hline $14: 17$ & 271 & $6: 15$ & 232 \\
\hline $16: 3$ & 220 & $7: 5$ & 87 \\
\hline $16: 7$ & 110 & $7: 16$ & 196 \\
\hline $16: 16$ & 271 & $7: 19$ & 117 \\
\hline $16: 20$ & 275 & $8: 1$ & 307 \\
\hline $18: 9$ & 60 & $8: 2$ & 307 \\
\hline $18: 10$ & 189 & $8: 13-14$ & 307 \\
\hline $18: 30$ & 37 & $10: 1-5$ & 307 \\
\hline $19: 24$ & 152 & $10: 4$ & $173,175,385$ \\
\hline \multirow[t]{2}{*}{$21: 6$} & 197 & $11: 25$ & 190 \\
\hline & & $12: 3$ & 326 \\
\hline \multicolumn{2}{|l|}{ Ruth } & $13: 36$ & 210 \\
\hline $2: 2$ & 321 & $17: 8$ & 397 \\
\hline $2: 13$ & 254 & $17: 19$ & 115 \\
\hline $2: 17$ & 320 & $18: 18$ & 86 \\
\hline $3: 2$ & 299 & $24: 12$ & 87 \\
\hline $3: 4$ & 37 & & \\
\hline $3: 7$ & 37 & 1 Kings & \\
\hline $3: 13$ & 280 & $4: 39$ & 321 \\
\hline \multirow[t]{2}{*}{$4: 16$} & 326 & $5: 1$ & 128,322 \\
\hline & & 7 & 116 \\
\hline \multicolumn{2}{|l|}{1 Samuel } & $7: 7$ & 81 \\
\hline $1: 3$ & 107 & $8: 10-11$ & 81 \\
\hline
\end{tabular}




\begin{tabular}{|c|c|c|c|}
\hline $8: 46-51$ & 249,261 & $20: 12$ & 126,129 \\
\hline $8: 65$ & 322 & $20: 12-19$ & $122-23,133$ \\
\hline $9: 7$ & 316 & $20: 13$ & 126 \\
\hline $10: 16-17$ & 116 & $20: 19$ & 135 \\
\hline $11: 17$ & 364 & $21: 1-18$ & 69,132 \\
\hline $11: 38$ & 196 & $21: 9$ & 361 \\
\hline $12: 15$ & 172 & $21: 14$ & 267 \\
\hline $13: 30$ & 33 & 22 & 195 \\
\hline $14: 15$ & 299 & $22: 14-20$ & 132 \\
\hline $17: 17-24$ & 205 & $22: 15-17$ & 132 \\
\hline $17: 39$ & 332 & $22: 18-20$ & 132 \\
\hline $18: 4$ & 268 & $23: 10$ & 106 \\
\hline $20: 31-32$ & 172 & $23: 12$ & 107 \\
\hline $22: 17$ & 298 & $23: 14-15$ & 320 \\
\hline \multirow[t]{2}{*}{$22: 27$} & 264 & $23: 26-27$ & 69,132 \\
\hline & & $23: 27$ & 409 \\
\hline 2 Kings & & $23: 30-35$ & 193 \\
\hline $1: 1$ & 360 & $23: 34$ & 199 \\
\hline $1: 8$ & 172 & $23: 37$ & 199 \\
\hline $2: 3$ & 60 & $24-25$ & $68-69,123$ \\
\hline $2: 10$ & 239 & $24: 3-4$ & 69,132 \\
\hline $4: 1$ & 277 & $24: 8-9$ & 193 \\
\hline $5: 7$ & 227 & $24: 8-17$ & $192-93$ \\
\hline $5: 11$ & 308 & $24: 10-12$ & 193 \\
\hline $5: 24$ & 217 & 24:14-16 & 193-94 \\
\hline $8: 1$ & 227 & $24: 17$ & 195 \\
\hline $8: 5$ & 227 & 24:10-19 & 68 \\
\hline $11: 3$ & 268 & $24: 12$ & 133,243 \\
\hline $12: 18$ & 171 & $24: 13$ & 133 \\
\hline $15: 29$ & 37 & $24: 14$ & 222 \\
\hline 16:9 & 106,113 & $24: 15$ & 133 \\
\hline $17: 4$ & 239,264 & $24: 20$ & 163 \\
\hline $17: 15$ & 409 & $24: 20-25: 21$ & 68 \\
\hline $17: 20$ & 267,409 & 25 & $27,110,243$ \\
\hline $17: 21$ & 299 & $25: 3$ & 110 \\
\hline $17: 23$ & 37 & $25: 4-6$ & 110 \\
\hline $17: 24$ & 133 & $25: 5$ & 297 \\
\hline $17: 30$ & 133 & $25: 7$ & 110,133 \\
\hline $18-19$ & 184 & $25: 9$ & 150 \\
\hline $18: 3-7$ & 135 & $25: 10$ & 113 \\
\hline 18:13-20:19 & 122 & $25: 11$ & 94 \\
\hline $18: 32$ & 316 & $25: 12$ & 222 \\
\hline $19: 26$ & 176 & $25: 13-17$ & 133 \\
\hline 20 & $8,204,206$ & $25: 20$ & 69 \\
\hline $20: 1-11$ & $127,205-6$ & $25: 21$ & 37 \\
\hline $20: 5$ & 231 & $25: 22-26$ & 6 \\
\hline $20: 7$ & 231 & $25: 26$ & 69,94 \\
\hline $20: 7-8$ & $205-6$ & $25: 27$ & 175,264 \\
\hline $20: 8$ & 231 & $25: 27-30$ & $70,132,194,243$ \\
\hline
\end{tabular}


1 Chronicles

$3: 17$

3:17-18

4:9

4:38

$4: 40$

$8: 8$

$20: 25$

29:3

2 Chronicles

24:24

26:16-21

26:21

28:14-15

29:6

$32: 31$

$33: 9$

36

$36: 4$

36:9-21

$36: 19$

$36: 21$

$36: 22-23$

Ezra

$1: 1-3$

$3: 8$

Nehemiah

1:3

$1: 8-9$

$5: 1-5$

$5: 8$

$7: 4$

9

9:15

Esther

2:3

$3: 15$

5:10

6:1

Job

1:21

2:10

$3: 7$

$3: 26$
265

243

262

404

189

316

267

150

145

240

240

173

188

126

361

68-69

199

69

$150-51$

$71-72$

70

70

250

113

300

277

304

189

137

332

132

112

61

226

173

47

397

262
4:11 38

$4: 21 \quad 220$

6:9 222

$7: 1 \quad 255$

$7: 4 \quad 226$

$7: 6 \quad 222$

$7: 9 \quad 42$

$\begin{array}{ll}7: 12 & 289\end{array}$

$\begin{array}{ll}7: 19 & 111\end{array}$

$8: 7 \quad 145$

10:8-9 $\quad 148$

10:16 223

10:19 238

$12: 14 \quad 190,272$

12:24-25 143

$12: 25 \quad 361$

$13: 24 \quad 50$

14:9 111

$14: 14 \quad 255$

$15: 34 \quad 397$

16:10 41

18:15 298

18:18 227

19:7 113

19:10 221

20:8 227

$20: 27 \quad 115$

$21: 32 \quad 238$

$22: 6 \quad 173$

$24: 7 \quad 38$

$26: 12 \quad 289$

27:20-21 $\quad 318$

$28: 28 \quad 339$

29:19 $\quad 371$

29:23 41

$30: 3 \quad 397$

$30: 6 \quad 268$

$32: 18 \quad 271$

$33: 24 \quad 283$

$33: 30 \quad 218$

$34: 29 \quad 50$

$35: 16 \quad 38$

$36: 29 \quad 108$

$38: 2 \quad 38$

$38: 10-11 \quad 42$

$38: 17 \quad 216$

$38: 41 \quad 223$

$39: 7 \quad 108$

$39: 16 \quad 143$ 


\begin{tabular}{|c|c|c|c|}
\hline \multirow{3}{*}{$\begin{array}{l}41: 5 \\
42: 3\end{array}$} & 116 & $42-43$ & 163,225 \\
\hline & 38 & $42: 3$ & 218,371 \\
\hline & & $42: 5$ & 225 \\
\hline Psalms & & $42: 7$ & 145 \\
\hline 1 & $340-41,368$ & $42: 8$ & 163 \\
\hline $1: 2$ & 224 & $42: 10$ & 390 \\
\hline $1: 3$ & 371 & $44: 10-12$ & 238 \\
\hline $2: 3$ & 276 & $44: 12$ & 299 \\
\hline $2: 7$ & 320 & $44: 13$ & $146,276-77$ \\
\hline $6: 4$ & 91 & $44: 18$ & 140 \\
\hline $6: 6$ & $229-30$ & $44: 23$ & 238 \\
\hline 9 & 81,216 & $44: 24$ & 142 \\
\hline $9: 5$ & 81 & $44: 25$ & 390 \\
\hline $9: 8$ & 81 & $45: 15-16$ & 238 \\
\hline $9: 14$ & 216 & $46: 4$ & 109 \\
\hline $9: 15$ & 216 & $46: 6$ & 65 \\
\hline $9: 16$ & 272 & $46: 7$ & 109 \\
\hline $13: 2$ & 390 & $48: 8$ & 318 \\
\hline $14: 2-3$ & 359 & $48: 15$ & 174,333 \\
\hline $15: 1$ & 219 & 49 & 82 \\
\hline $16: 10$ & 272 & $49: 2$ & 219 \\
\hline $17: 14$ & 219 & $49: 8$ & 283 \\
\hline 18 & 213 & $49: 12$ & 188 \\
\hline $18: 7$ & 113 & $49: 13$ & 82 \\
\hline $18: 29$ & 48 & $49: 21$ & 82 \\
\hline $22: 2$ & 142,390 & $51: 8$ & 224 \\
\hline $22: 16$ & 275 & $52: 3-7$ & 218 \\
\hline $22: 30$ & 275 & $52: 7$ & 218,222 \\
\hline $23: 1$ & 222 & $55: 11$ & 197 \\
\hline $23: 2$ & 325 & $55: 18$ & 109 \\
\hline $24: 3$ & 107,232 & $56: 2-3$ & 61 \\
\hline $24: 3-4$ & 84 & $56: 8$ & 287 \\
\hline $24: 8$ & 55,60 & $56: 14$ & 218 \\
\hline $28: 1$ & 60,229 & $58: 4$ & 359,362 \\
\hline $28: 5$ & 35,190 & $59: 14$ & 146 \\
\hline $28: 7$ & 109 & $61: 5$ & 219 \\
\hline $29: 9$ & 175 & $63: 2$ & 372 \\
\hline 30 & 213,230 & $65: 7$ & 43 \\
\hline $30: 4$ & 164,229 & $66: 12$ & 282 \\
\hline $30: 6$ & 49 & $68: 5$ & 109 \\
\hline $30: 10$ & 229 & $68: 30$ & 238 \\
\hline $31: 7$ & 108 & $69: 3$ & 321 \\
\hline $31: 23$ & 163,240 & $69: 16$ & 321 \\
\hline 32 & 213 & $71: 20$ & 164 \\
\hline 34 & 213 & 74 & $67,92,144$ \\
\hline $34: 15$ & 34 & $74: 1$ & 142 \\
\hline $39: 2$ & 60 & $74: 2$ & 144,304 \\
\hline $39: 5$ & 219 & $74: 3-7$ & 150 \\
\hline $40: 18$ & 370 & $74: 3-8$ & 149 \\
\hline
\end{tabular}




\begin{tabular}{|c|c|c|c|}
\hline $74: 5-6$ & 151 & $103: 13$ & 140 \\
\hline $74: 7$ & 144 & $103: 15-16$ & 318 \\
\hline $74: 9-10$ & 92 & $104: 4$ & 330 \\
\hline $74: 10$ & 144,278 & $104: 9$ & 42 \\
\hline $74: 13$ & 162 & $104: 25$ & 189 \\
\hline $74: 13-14$ & 307 & $105: 39$ & 115 \\
\hline $74: 18$ & 278 & 106 & 137 \\
\hline $74: 23$ & 43 & $106: 9$ & 289 \\
\hline $75: 9$ & 56 & $106: 27$ & 299 \\
\hline $76: 6$ & 360 & $107: 2-3$ & 328 \\
\hline $76: 12$ & 238 & $107: 4-5$ & 40 \\
\hline $77: 4$ & 109 & $107: 5$ & 332,371 \\
\hline $77: 10$ & 390 & $107: 10$ & 265 \\
\hline $78: 4$ & 55 & $107: 14$ & 276 \\
\hline $78: 13$ & 289 & $107: 14-16$ & 287 \\
\hline $78: 40$ & 140 & $107: 18$ & 216 \\
\hline $78: 52$ & $174,220,325,333$ & $107: 27$ & 156 \\
\hline $78: 54$ & 305 & $107: 35-43$ & 372 \\
\hline $78: 59$ & 409 & $107: 39$ & 239 \\
\hline $78: 67$ & 409 & 109:10 & 156 \\
\hline 79 & 68,92 & $113: 9$ & 401 \\
\hline $79: 1$ & $144,149,274$ & $115: 4-9$ & 357 \\
\hline $79: 5$ & 92 & $115: 17$ & 64,229 \\
\hline $79: 11$ & 272 & $116: 16$ & 276 \\
\hline $80: 2$ & 174,333 & 119 & 349 \\
\hline $80: 5$ & 91 & $119: 18$ & 116 \\
\hline $80: 9$ & 220 & $119: 122$ & 225 \\
\hline $81: 3$ & 34 & 119:131 & 41,61 \\
\hline $81: 4$ & 322 & $119: 176$ & 361 \\
\hline $83: 2$ & $60,63,215$ & $122: 1$ & 232 \\
\hline $87: 4$ & 289 & $122: 5$ & 81 \\
\hline $88: 5$ & 42,229 & $124: 7$ & 268 \\
\hline $88: 6$ & 240 & $131: 2$ & 223 \\
\hline $88: 11-12$ & 229 & $136: 13-14$ & 289 \\
\hline 89 & 68 & 137 & $68,164,249$ \\
\hline $89: 11$ & 289 & $137: 3$ & 261 \\
\hline $89: 29$ & 196 & $139: 7-12$ & 157 \\
\hline 90 & 92 & $139: 8$ & 42 \\
\hline $90: 15$ & 151 & $145: 6$ & 55 \\
\hline $92: 2-5$ & 34 & $146: 7-8$ & 264 \\
\hline 94 & 92 & $150: 3$ & 322 \\
\hline $94: 17$ & 64 & & \\
\hline $95: 8$ & 143 & Proverbs & \\
\hline $95: 10$ & 362 & $1: 12$ & 42 \\
\hline $96: 12$ & 109 & $2: 6$ & 339 \\
\hline $98: 2$ & 37,115 & $2: 22$ & 218 \\
\hline $102: 20-21$ & 272 & $4: 1-2$ & 339 \\
\hline $103: 3-4$ & 229 & $4: 4$ & 340 \\
\hline $103: 12$ & 94,229 & $4: 10-19$ & 340 \\
\hline
\end{tabular}




\begin{tabular}{|c|c|c|c|}
\hline $4: 23$ & 88 & $1: 1$ & 106,336 \\
\hline $6: 35$ & 283 & $1: 2$ & 360 \\
\hline $7: 11$ & 109 & $1: 2-3$ & $280,336,341,348$ \\
\hline $7: 23$ & 268 & $1: 2-4$ & $57,140,377$ \\
\hline $7: 25$ & 362 & $1: 3$ & $36,38,87-88,253$, \\
\hline $8: 22$ & 305 & & 304,312 \\
\hline $8: 29$ & 42 & $1: 3-4$ & 89 \\
\hline $9: 1-6$ & 340 & $1: 4$ & $30,33,87,97,99$ \\
\hline 9:10 & 38,339 & & $120,149,255,278$ \\
\hline $9: 13-18$ & 340 & & 319,350 \\
\hline $10: 17$ & 362 & $1: 5-6$ & $90,235,314$ \\
\hline $11: 13$ & 115 & $1: 6$ & 203 \\
\hline $12: 5$ & 364 & $1: 7$ & $33,46,93,149$ \\
\hline $12: 26$ & 362 & $1: 7-9$ & 304 \\
\hline $13: 8$ & 283 & $1: 8$ & 384 \\
\hline $14: 22$ & 362 & $1: 8-9$ & $27,133,312$ \\
\hline $14: 23$ & 262 & $1: 10$ & 87,131 \\
\hline $15: 7$ & 298 & $1: 11$ & 45 \\
\hline $15: 13$ & 408 & $1: 12$ & 218 \\
\hline $16: 6$ & 120 & $1: 13$ & 109 \\
\hline $16: 28$ & 376 & $1: 21$ & 108,384 \\
\hline $20: 1$ & 34 & $1: 21-28$ & 98 \\
\hline $20: 12$ & 339 & $1: 23$ & 34 \\
\hline $21: 16$ & 362 & $1: 25$ & 58 \\
\hline $23: 11$ & 280 & $1: 29-31$ & 98 \\
\hline $23: 29-35$ & 34 & $1: 30$ & 141,375 \\
\hline $24: 30-34$ & 339 & 2 & 112 \\
\hline $25: 4-5$ & 318 & $2: 1-4$ & 9 \\
\hline $25: 9$ & 115 & $2: 2$ & $231-32$ \\
\hline $26: 20$ & 156 & $2: 2-4$ & $28,66,233,323$, \\
\hline $27: 20$ & 41 & & $330,342,371$ \\
\hline $28: 14$ & 143 & $2: 3$ & 371 \\
\hline $30: 15-16$ & 41 & $2: 6-22$ & 44 \\
\hline \multirow[t]{2}{*}{$30: 16$} & 239 & $2: 8$ & 323 \\
\hline & & $2: 9$ & 31,43 \\
\hline Ecclesiastes & & $2: 10$ & 43 \\
\hline $3: 7$ & 60 & $2: 11$ & 31,43 \\
\hline \multirow[t]{2}{*}{$4: 14$} & 390 & $2: 17$ & 31,43 \\
\hline & & $2: 19$ & 43 \\
\hline Song of Songs & & $2: 20$ & 323 \\
\hline $4: 16$ & 330 & $2: 21$ & 43 \\
\hline \multirow[t]{2}{*}{$7: 6$} & 222 & 3 & 93 \\
\hline & & $3: 9$ & 83 \\
\hline Isaiah & & $3: 11$ & 83 \\
\hline $1-5$ & 43,89 & $3: 12$ & $87,142,362-63$ \\
\hline $1-12$ & 58,295 & $3: 13$ & 316 \\
\hline \multirow[t]{3}{*}{$1-39$} & $7-8,10-11,16,22-$ & $3: 14$ & 87,98 \\
\hline & $24,67,136,166$ & $3: 14-15$ & 370 \\
\hline & $247,253,255$ & $3: 15$ & 87 \\
\hline
\end{tabular}




\begin{tabular}{|c|c|c|c|}
\hline $3: 16-4: 1$ & 39,384 & $5: 17$ & $31,36,40,44-45$ \\
\hline $3: 17$ & 173 & & $49,98,149,151$ \\
\hline $3: 20$ & 395 & & 292,396 \\
\hline $3: 24$ & 172 & $5: 19$ & 35 \\
\hline $3: 26$ & 93,385 & $5: 21$ & 343 \\
\hline $4: 1$ & $394,405,407$ & $5: 22$ & 34,57 \\
\hline $4: 2-6$ & 98,304 & $5: 24$ & 35,278 \\
\hline $4: 3$ & 133 & $5: 24-25$ & 55 \\
\hline $4: 4-5$ & 58 & $5: 25$ & $87,97,256,304$ \\
\hline $4: 5-6$ & 115 & & 314 \\
\hline 5 & 30,45 & $5: 25-30$ & 30,112 \\
\hline $5: 1$ & 76 & $5: 25-11: 16$ & 301 \\
\hline $5: 1-7$ & $30,310-11,341$ & $5: 26$ & $114,304,334,391$ \\
\hline $5: 2$ & 187 & $5: 29$ & 223 \\
\hline $5: 3$ & 33 & $5: 30$ & 65 \\
\hline $5: 5$ & 98,404 & 6 & $44,74-78,81-83$ \\
\hline $5: 6$ & 45,293 & & $87,93,96,99,137$ \\
\hline $5: 7$ & $30,33,43$ & & $146,152,236,251-$ \\
\hline $5: 8-24$ & 29,311 & & $52,254,325,378$ \\
\hline $5: 9$ & $76,93,120,149$ & $6: 1$ & $79-81,171,303$ \\
\hline $5: 10$ & 45 & $6: 1-4$ & $79-80$ \\
\hline $5: 11$ & 34,57 & $6: 1-7$ & 74,78 \\
\hline $5: 11-12$ & $29-30,34,38-40$ & $6: 1-11$ & 97 \\
\hline $5: 11-13$ & $\begin{array}{l}31,39,119,343 \\
363\end{array}$ & $6: 1-13$ & $\begin{array}{l}16,67,74,100 \\
152,234,290,411\end{array}$ \\
\hline \multirow[t]{4}{*}{$5: 11-17$} & $16,19,29-32,45-$ & $6: 1-8: 18$ & 75,78 \\
\hline & $47,54,66-67,98$ & $6: 1-9: 6$ & 75 \\
\hline & $104,107,132,178$ & $6: 1-11: 16$ & 9 \\
\hline & $311,336,411$ & $6: 3$ & 90,251 \\
\hline \multirow[t]{2}{*}{$5: 12$} & $35,38-39,43,88$ & $6: 4$ & 90 \\
\hline & $\begin{array}{l}117,148-49,171, \\
219\end{array}$ & $6: 5$ & $\begin{array}{l}79,81-83,87,131, \\
141,146,215,238\end{array}$ \\
\hline $5: 12-13$ & 377 & & 274,286 \\
\hline \multirow{4}{*}{$5: 13$} & $11,29,31,33,35-$ & $6: 5-7$ & $79,82,91,351$ \\
\hline & $38,40-42,46,57$ & $6: 7$ & $84,98,120,149$ \\
\hline & $87-88,253,332$, & & 255,319 \\
\hline & $352,371,397$ & $6: 8$ & $79-80,85,91,303$ \\
\hline \multirow[t]{2}{*}{$5: 13-14$} & $11,44,46,108$ & $6: 8-10$ & 85,87 \\
\hline & $163,215,258,295$ & $6: 8-13$ & $74,78,85$ \\
\hline $5: 13-17$ & $29-30,33,35,44$ & $6: 9$ & $87,146,172,266$ \\
\hline \multirow[t]{3}{*}{$5: 14$} & $29-30,36,41-43$ & & 346 \\
\hline & $\begin{array}{l}46,64,98,109, \\
\text {, }\end{array}$ & $6: 9-10$ & $34,87,91,96,104$, \\
\hline & $\begin{array}{l}119,216,272,288, \\
363,412\end{array}$ & & $\begin{array}{l}131,141-42,152, \\
179,236,264,291,\end{array}$ \\
\hline $5: 14-17$ & 31 & & $336-37,346-48$ \\
\hline $5: 15$ & 44 & & 352,377 \\
\hline $5: 15-16$ & $31,43,45,80$ & $6: 9-13$ & 120 \\
\hline $5: 16$ & 43 & & \\
\hline
\end{tabular}




\begin{tabular}{|c|c|c|c|}
\hline \multirow[t]{3}{*}{$6: 10$} & $86,88-90,92,96$ & $9: 5$ & 195 \\
\hline & $98,143,254,315$ & $9: 6$ & 60,342 \\
\hline & 359 & $9: 7-10: 4$ & 54 \\
\hline \multirow[t]{3}{*}{$6: 11$} & $80,85-86,91-95$ & $9: 11$ & 304 \\
\hline & $98,108,142,149$ & $9: 12$ & 97,314 \\
\hline & 152,252 & $9: 15$ & 42,362 \\
\hline $6: 11-12$ & $97-98,232,396$ & $9: 16$ & 304 \\
\hline \multirow[t]{5}{*}{$6: 11-13$} & $9,14,78-79,83$ & $9: 17$ & $97-98$ \\
\hline & $85,91-92,100$ & $9: 20$ & 304,306 \\
\hline & $123,132-33,136$ & $9: 21$ & 97 \\
\hline & $152,252,352,360$ & $10: 1$ & 393 \\
\hline & 391 & $10: 1-4$ & 30 \\
\hline \multirow[t]{2}{*}{$6: 12$} & $94-95,98,130$ & $10: 3$ & 130 \\
\hline & 295,385 & $10: 4$ & 97,304 \\
\hline $6: 12-13$ & $77,92,97$ & $10: 5-34$ & 301 \\
\hline \multirow[t]{2}{*}{$6: 13$} & $11,58,77,86-87$ & $10: 6$ & 267,286 \\
\hline & 97-99, 291-92 & $10: 11$ & 356 \\
\hline 7 & 165 & $10: 12$ & 217 \\
\hline $7-8$ & $75-76$ & $10: 13$ & 267 \\
\hline $7: 1-2$ & 129 & $10: 14$ & 224 \\
\hline $7: 1-9$ & 124 & $10: 17$ & 98 \\
\hline $7: 2$ & $112,210,308$ & $10: 20-23$ & 304 \\
\hline \multirow[t]{2}{*}{$7: 3$} & $98,116-17,129$ & $10: 20-27$ & 314 \\
\hline & 304 & $10: 21$ & 60 \\
\hline $7: 8$ & 174 & $10: 24-34$ & 175 \\
\hline $7: 9$ & 117 & $10: 26$ & 308 \\
\hline $7: 11$ & 42,232 & $10: 31$ & 226 \\
\hline $7: 13$ & 210 & $10: 32$ & 106,308 \\
\hline $7: 14$ & 232 & $10: 33$ & 197 \\
\hline $7: 16$ & 174 & $10: 33-34$ & 99 \\
\hline $7: 23-26$ & 93 & 11 & 301,303 \\
\hline $7: 25$ & 45,98 & $11: 1$ & 99 \\
\hline $8: 5-8$ & 51 & $11: 1-9$ & 301 \\
\hline $8: 7$ & 307 & $11: 1-10$ & 303 \\
\hline $8: 7-8$ & 49 & $11: 2$ & 38,342 \\
\hline $8: 11$ & 363 & $11: 2-3$ & 143 \\
\hline $8: 12-15$ & 51 & 11:9 & $149,305,323,377$ \\
\hline $8: 15$ & 35 & $11: 10$ & 301,305 \\
\hline $8: 16-18$ & $51,59,83$ & $11: 11$ & $301,303,305,307$ \\
\hline $8: 17$ & 51,65 & & $320,325,327-28$ \\
\hline $8: 18$ & 27,174 & & 377 \\
\hline $8: 19$ & 224 & $11: 11-12$ & $301,303,306-7$, \\
\hline $8: 21-22$ & 65 & & $328,334,394$ \\
\hline $8: 21-9: 1$ & 265 & $11: 11-13$ & 307 \\
\hline $8: 22$ & 300 & $11: 11-16$ & $9,278,295-96$ \\
\hline $8: 22-9: 1$ & 365 & & $301-2,304,309$ \\
\hline $8: 23-9: 6$ & 51 & & $322-23,333,412$ \\
\hline $9: 1$ & 65 & $11: 12$ & $298,304-5,308$ \\
\hline $9: 3$ & 261 & & $322,327,330-31$ \\
\hline
\end{tabular}




\begin{tabular}{|c|c|c|c|}
\hline $11: 12-16$ & 301 & $14: 19$ & 229 \\
\hline $11: 13$ & 306 & $14: 20$ & 271 \\
\hline $11: 13-14$ & $301,306,327$ & $14: 22-23$ & 259 \\
\hline $11: 14$ & $307-8,404$ & $14: 24-28$ & 27 \\
\hline \multirow[t]{2}{*}{$11: 15$} & 307-9, 314, 318, & $14: 25$ & 112 \\
\hline & $320,365,372$ & $14: 26$ & 97 \\
\hline $11: 15-16$ & $301,303,307,311$ & $14: 28$ & 171 \\
\hline $11: 16$ & $300,309,333$ & $14: 29$ & 81 \\
\hline 12 & $295,301,371$ & $15: 1$ & $65,82,215$ \\
\hline $12: 1$ & 59,252 & $15: 2-3$ & 118 \\
\hline $12: 2$ & 213 & $15: 3$ & 107 \\
\hline $12: 3$ & 371 & $16: 3$ & 37,226 \\
\hline $13-14$ & $101,134,216,257$ & $16: 3-4$ & 300 \\
\hline $13-19$ & 101 & $16: 11$ & 111 \\
\hline \multirow[t]{2}{*}{$13-23$} & $100-3,106,134$ & $16: 14$ & 174 \\
\hline & $147,165,184$ & $17: 2$ & 45,98 \\
\hline $13-26$ & 312 & $17: 3$ & 115 \\
\hline $13: 1$ & 259 & $17: 3-11$ & $310-11$ \\
\hline $13: 1-14: 23$ & $102,259,312$ & $17: 9$ & 96 \\
\hline $13: 2$ & 308 & $17: 10$ & 392 \\
\hline $13: 2-22$ & 259 & $17: 12$ & 109 \\
\hline $13: 3$ & 109 & $17: 12-13$ & 43,108 \\
\hline $13: 10$ & 65 & $17: 12-14$ & 27 \\
\hline $13: 11$ & $217,241,269$ & $17: 13$ & 50,318 \\
\hline $13: 14$ & 299 & $17: 13-14$ & 65 \\
\hline $13: 16$ & 387 & $17: 14$ & 267 \\
\hline $13: 18$ & 114 & 18 & 165 \\
\hline $13: 20-22$ & 45 & $18: 4$ & 62 \\
\hline $13: 21-22$ & 292 & $18: 7$ & 238,322 \\
\hline $13: 22$ & 81 & 19 & 165 \\
\hline $14: 1$ & $259-60$ & $19: 13-14$ & 361 \\
\hline $14: 1-2$ & 9,259 & $19: 16$ & 308 \\
\hline \multirow[t]{2}{*}{$14: 1-4 a$} & $250,258-59,267$ & $19: 18-25$ & 9 \\
\hline & 412 & $19: 22$ & 91 \\
\hline \multirow[t]{2}{*}{$14: 2$} & $133,258,260-62$ & $19: 25$ & 55,309 \\
\hline & $\begin{array}{l}269-70,276,330, \\
396\end{array}$ & 20 & $\begin{array}{l}11,76,82,101 \\
128,165-69,174\end{array}$ \\
\hline $14: 3$ & $255,262-63$ & & $178,181,190,239$, \\
\hline $14: 3-4 a$ & 259 & & 248,394 \\
\hline $14: 4-5$ & 261 & $20: 1$ & $165,171,176$ \\
\hline \multirow[t]{2}{*}{$14: 4-21$} & 134, 259, 262, 293, & $20: 1-2$ & 167 \\
\hline & 388 & $20: 1-4$ & $165-66$ \\
\hline $14: 4-23$ & 271 & $20: 1-6$ & $16,101,154,165-$ \\
\hline $14: 5$ & 241 & & $66,170,182,232$ \\
\hline $14: 11$ & 42 & & 234,412 \\
\hline $14: 12$ & 197 & $20: 2$ & $87,165,167-69$ \\
\hline $14: 15$ & 42,288 & & 172 \\
\hline $14: 17$ & $190,265,272,394$ & $20: 2-4$ & $171,309,379$ \\
\hline $14: 18$ & 188 & $20: 2-5$ & 166 \\
\hline
\end{tabular}




\begin{tabular}{|c|c|c|c|}
\hline $20: 3$ & $\begin{array}{l}165,168-69,174 \\
180\end{array}$ & $\begin{array}{l}22: 9 \\
22: 10\end{array}$ & $\begin{array}{l}118 \\
118\end{array}$ \\
\hline $20: 3-4$ & $\begin{array}{l}165,168,172-73 \\
201,295\end{array}$ & $22: 11$ & $\begin{array}{l}117,119,148-49 \\
171,178,219,377\end{array}$ \\
\hline $20: 3-5$ & 177 & $22: 12$ & $110,116,118-19$ \\
\hline \multirow[t]{2}{*}{$20: 4$} & $167-68,173-75$ & & $183,186,195$ \\
\hline & $238,276,333,385$ & $22: 12-13$ & $100,103,118$ \\
\hline $20: 5$ & $166-67,176$ & $22: 12-14$ & 120 \\
\hline $20: 5-6$ & 165,175 & $22: 14$ & $37,100,103,116$ \\
\hline $20: 6$ & $166,176-77$ & & $119,131,149,183$ \\
\hline $21-23$ & $101-2$ & & $256,284,319$ \\
\hline $21: 1$ & 101 & $22: 15$ & $172,183,186,190$ \\
\hline $21: 1-10$ & 102 & & 91 \\
\hline $21: 2$ & 113 & $22: 15-16$ & 186 \\
\hline $21: 3$ & 111 & $22: 15-19$ & $183,185,241$ \\
\hline $21: 11$ & 64 & $22: 15-25$ & $17,101-2,154$ \\
\hline $21: 11-12$ & $63-65$ & & $183,198,200,234$ \\
\hline $21: 12$ & 65 & & 248,412 \\
\hline $21: 13$ & 101 & $22: 16$ & 186-87, 189-90, \\
\hline $21: 13-17$ & 63 & & 393 \\
\hline $21: 14$ & 226 & $22: 17$ & 186 \\
\hline $21: 15$ & 226 & $22: 17-18 a$ & $186,188-90,192$ \\
\hline $21: 16$ & 174 & & $201,295,379$ \\
\hline \multirow[t]{2}{*}{22} & $102,115-16,183-$ & $22: 17-19$ & 188 \\
\hline & 84,190 & $22: 18 b$ & $186,189,192,196$ \\
\hline \multirow[t]{2}{*}{$22: 1$} & 101, 106-9, 111, & $22: 19$ & 183,190 \\
\hline & 130 & $22: 20-23$ & $183,195-99,210$ \\
\hline \multirow[t]{2}{*}{$22: 1-4$} & $100,102-3,113$ & $22: 20-24$ & 173,183 \\
\hline & 116 & $22: 20-25$ & $183,194-96$ \\
\hline \multirow[t]{5}{*}{$22: 1-14$} & $16,46,67,100$ & $22: 21$ & 394 \\
\hline & $102,104,121,132$ & $22: 22$ & 264 \\
\hline & $147,153,183-84$ & $22: 24$ & $196-97$ \\
\hline & $186,234,290,311$ & $22: 25$ & $183,195-97$ \\
\hline & $337,379,411$ & 23 & 102,109 \\
\hline \multirow[t]{2}{*}{$22: 2$} & $43,106-11,113$ & $23: 1$ & 37 \\
\hline & 118,199 & $23: 2$ & 176 \\
\hline \multirow[t]{2}{*}{$22: 3$} & $107,109-10,199$ & $23: 6$ & 176 \\
\hline & 226,363 & $23: 7$ & 109 \\
\hline $22: 4$ & $\begin{array}{l}36,103,107,110- \\
12,119,253,385\end{array}$ & $24-27$ & $\begin{array}{l}44-45,295,309, \\
310\end{array}$ \\
\hline \multirow[t]{2}{*}{$22: 5$} & $106,112-13,116$ & $24: 1$ & 298 \\
\hline & 183,186 & $24: 1-3$ & 310 \\
\hline $22: 5-8 a$ & $100,103,112$ & $24: 2$ & 190 \\
\hline $22: 6$ & $113-14$ & $24: 8$ & 109 \\
\hline $22: 7$ & $113-14$ & $24: 8-9$ & 35,43 \\
\hline \multirow[t]{2}{*}{$22: 8$} & $37,114-16,119$ & $24: 10-12$ & 45 \\
\hline & $171,195,398$ & $24: 11$ & 37 \\
\hline $22: 8 b-11$ & $103,116,199,215$ & $24: 16$ & 83 \\
\hline $22: 8 b-13$ & 100 & $24: 20$ & 156 \\
\hline
\end{tabular}




\begin{tabular}{|c|c|c|c|}
\hline $24: 21-22$ & 217 & $28: 16$ & 117 \\
\hline $24: 22$ & 264 & $28: 23-29$ & $341-42$ \\
\hline $25: 2-3$ & 45 & $28: 25$ & 297 \\
\hline $25: 6$ & 34 & $28: 26$ & 342 \\
\hline $25: 8$ & 322 & $28: 27$ & 320 \\
\hline $25: 11-12$ & 44 & $29: 1$ & 106 \\
\hline $26: 1$ & 44 & $29: 1-8$ & 27,106 \\
\hline $26: 4$ & 213 & $29: 2$ & 271 \\
\hline $26: 5$ & $44-45$ & $29: 4$ & 224 \\
\hline $26: 11$ & 60 & $29: 5$ & 109,355 \\
\hline $26: 14$ & 217,322 & $29: 7$ & 271 \\
\hline $26: 19$ & 275,322 & $29: 9-10$ & 337 \\
\hline $26: 20-21$ & 315 & $29: 13$ & 254 \\
\hline $26: 21$ & $37,115,217$ & $29: 14$ & 343 \\
\hline 27 & 310 & $29: 16$ & $147-48$ \\
\hline \multirow[t]{3}{*}{$27: 1$} & $162,217,289,310$ & $29: 17$ & 373 \\
\hline & $12,315,320-21$ & $29: 17-21$ & 376 \\
\hline & 325 & $29: 17-24$ & 373,375 \\
\hline $27: 2-6$ & $310-11,314,321$ & $29: 18$ & 336,346 \\
\hline $27: 4$ & 312 & $29: 23$ & 148,375 \\
\hline $27: 6$ & 314 & $29: 24$ & 376 \\
\hline $27: 7$ & $311-15,319,332$ & 30 & 140 \\
\hline $27: 7-9$ & 312,314 & $30: 1$ & 140 \\
\hline $27: 7-11$ & 310 & $30: 1-5$ & 175 \\
\hline \multirow[t]{2}{*}{$27: 7-13$} & $45,295-96,309-$ & $30: 6$ & 81 \\
\hline & $12,323,412$ & $30: 7$ & 289 \\
\hline \multirow[t]{3}{*}{$27: 8$} & $308,311,313,315-$ & $30: 8$ & 351,393 \\
\hline & $16,318,321,330$ & $30: 9$ & 88,140 \\
\hline & 333,391 & $30: 9-11$ & 337,351 \\
\hline $27: 8-9$ & $120,284,315$ & $30: 11$ & 351 \\
\hline \multirow[t]{2}{*}{$27: 9$} & $120,310-11,316$ & $30: 15$ & 88,109 \\
\hline & $318-19,322-23$ & $30: 20$ & 366 \\
\hline $27: 10$ & 45 & $30: 20-22$ & 366 \\
\hline $27: 10-11$ & $311-12,314$ & $30: 21$ & 367 \\
\hline $27: 11$ & 321 & $30: 23-26$ & 315 \\
\hline \multirow[t]{2}{*}{$27: 12$} & $311,317,320-21$, & $30: 24$ & 299 \\
\hline & 329,331 & $30: 25$ & 315 \\
\hline \multirow[t]{2}{*}{$27: 12-13$} & $9,295,310-12$ & $30: 26$ & 90,203 \\
\hline & $320,323,327$ & $30: 27$ & 55 \\
\hline \multirow[t]{2}{*}{$27: 13$} & $311,322-23,327$ & $30: 27-33$ & 60,314 \\
\hline & 331,333 & $30: 30$ & 55 \\
\hline $28: 1$ & 34 & $30: 32$ & 140 \\
\hline $28: 1-4$ & 34,252 & $31: 1-3$ & 117,176 \\
\hline $28: 2$ & 256 & $31: 3$ & 256 \\
\hline \multirow[t]{2}{*}{$28: 7$} & $34-35,57,337$ & $31: 4$ & $55,109,224$ \\
\hline & 361,363 & $32: 3-4$ & 346 \\
\hline $28: 7-13$ & $34-35,337$ & $32: 14$ & 45,98 \\
\hline $28: 12$ & 88 & $32: 15-18$ & 373 \\
\hline $28: 14$ & 131 & $32: 19$ & 44 \\
\hline
\end{tabular}




\begin{tabular}{|c|c|}
\hline 33 & 25 \\
\hline $33: 3$ & 226,320 \\
\hline $33: 5$ & 188,346 \\
\hline $33: 6$ & $38,143,342$ \\
\hline $33: 9$ & 275 \\
\hline $33: 14-24$ & 98 \\
\hline $33: 20$ & 195,220 \\
\hline $33: 21$ & 189 \\
\hline $33: 24$ & 120 \\
\hline $34-35$ & 25 \\
\hline $34: 2$ & 308 \\
\hline $34: 5$ & 308 \\
\hline $34: 13-14$ & 292 \\
\hline $34: 14$ & 64 \\
\hline $35: 1-10$ & 373 \\
\hline $35: 5$ & 336,359 \\
\hline $35: 5-7$ & 374 \\
\hline $35: 8$ & 366 \\
\hline $35: 8-10$ & 374 \\
\hline $35: 9$ & 279 \\
\hline $35: 10$ & 119,279 \\
\hline $36-37$ & $\begin{array}{l}21,27,121,128 \\
165-66,184,190 \\
198,201,209-10\end{array}$ \\
\hline $36-38$ & 125,135 \\
\hline $36-39$ & $23,25-26,76,121$ \\
\hline $36: 3$ & 185 \\
\hline $36: 10$ & 271 \\
\hline $36: 17$ & 133 \\
\hline $37-38$ & $231-32$ \\
\hline $37: 1$ & $108,172,200,231$ \\
\hline $37: 2$ & 185 \\
\hline $37: 3$ & 112 \\
\hline $37: 8$ & 220 \\
\hline $37: 11$ & 308 \\
\hline $37: 14$ & 126,231 \\
\hline $37: 16-20$ & 375 \\
\hline $37: 21-29$ & 384 \\
\hline $37: 22$ & 386 \\
\hline $37: 26$ & 108 \\
\hline $37: 27$ & 176 \\
\hline $37: 30$ & 174 \\
\hline $37: 30-32$ & 304 \\
\hline $37: 32$ & 60 \\
\hline $37: 35$ & 210 \\
\hline $37: 36$ & 65,118 \\
\hline $37: 36-38$ & 314 \\
\hline $37: 37$ & 220 \\
\hline
\end{tabular}

38

38-39

$38: 1$

$38: 1-8$

$38: 1-22$

38:5

$38: 5-6$

$38: 7-8$

$38: 8$

$38: 9$

38:9-20

$38: 10$

$38: 10-12 \mathrm{a}$

$38: 10-17 \mathrm{a}$

$38: 11$

38:12

$38: 12 b-14$

$38: 13$

$38: 14$

$38: 15$

$38: 15-16$

$38: 15-17 \mathrm{a}$

$38: 16$

$38: 17$

$38: 17 b-20$

$38: 18$

$38: 19$

$38: 20$

$38: 21$

$38: 21-22$

$38: 22$

39
21, 121-22, 129, 135, 155, 200-2, 204-9, 231-34, 248, 335

8,25

210

129, 200, 205-6, 209, 231

17, 154, 200, 234, 412

87

206, 209-10

232

206, 229

126, 210, 213-14, 235

200, 204-5, 207, 211-13, 258 63, 164, 213-17, 219, 228-30, 272, 287

214, 218, 295

213

213, 217, 219, 240

37, 188, 219-24, 240

214, 222

223-24

224, 229

225-27, 230

213,225

214,225

126, 210, 227

149, 213, 222-29,

241, 272

213, 214, 228

229-30, 241, 288

213, 230

209, 214, 216, 219 ,

230-31

126, 129, 174, 203,

210, 230-31

200, 205, 207-9,

231

107, 206, 209, 226,

231-32

$1,11,13,16,19-$

20, 22, 24, 26-29,

31, 46-48, 54, 59, 


\begin{tabular}{|c|c|c|c|}
\hline & $66-67,78,83,99-$ & & $262,270,280,284$, \\
\hline & $100,121-23,125$ & & $293,391,412$ \\
\hline & $127,134,152-53$ & $40: 1-9$ & 324 \\
\hline & $200-1,209,234$ & $40: 1-11$ & $251,324-25$ \\
\hline & $236,248,250-51$ & $40: 2$ & $26,56,253-57$ \\
\hline & $254,256,290,337$ & & $262,319,377,385$ \\
\hline & $384,395,411-13$ & $40: 3$ & 309 \\
\hline 39:1 & 127,134 & $40: 3-5$ & 366 \\
\hline $39: 1-2$ & $121,129,131$ & $40: 5$ & $37,120,324$ \\
\hline $39: 1-8$ & $16,25,67,121-22$ & $40: 7$ & 252,318 \\
\hline & $125,136,153,234$ & $40: 7-8$ & 141 \\
\hline & $257,290,411$ & $40: 9$ & 324 \\
\hline $39: 2$ & $126-27,129-33$ & $40: 10$ & $146,286,324-27$ \\
\hline $39: 3$ & $127,129,334$ & & 333 \\
\hline $39: 3-4$ & $121,130-31$ & $40: 10-11$ & $296,298,300,324$ \\
\hline $39: 4$ & $129,132-33$ & & $327,394,412$ \\
\hline $39: 5-7$ & 20,131 & $40: 11$ & $325-26,331-32$, \\
\hline $39: 5-8$ & 121 & & 385,391 \\
\hline $39: 6$ & $124,129,131,133$ & $40: 12-14$ & 342 \\
\hline & 151,394 & $40: 14$ & 38 \\
\hline $39: 6-7$ & $26,132,134,216-$ & $40: 16$ & 98 \\
\hline & 17,295 & $40: 18-20$ & 54,357 \\
\hline $39: 7$ & $81,129,133$ & $40: 26$ & 358 \\
\hline $39: 7-8$ & 124 & $40: 27$ & $51,53,61,344$ \\
\hline $39: 8$ & $21,126,134-35$ & & 361,389 \\
\hline & 228 & $40: 27-31$ & 389 \\
\hline $39: 8-40: 1$ & 19 & $41: 1$ & 281 \\
\hline 40 & $1,11,13,16,19$ & $41: 1-7$ & $347,353,368$ \\
\hline & $20,22-24,26-29$ & $41: 1-42: 12$ & 368 \\
\hline & $31,46-48,54,59$ & $41: 2-3$ & 281 \\
\hline & $66-67,78,83,99-$ & $41: 5$ & 177 \\
\hline & $100,123,134,152-$ & $41: 6-7$ & 54,357 \\
\hline & $53,200,225,234$ & $41: 8-9$ & 260,328 \\
\hline & $236,248,250-51$ & $41: 14$ & 370 \\
\hline & $254,256,290,293$ & $41: 15-16$ & 318 \\
\hline & $337,384,395,411-$ & $41: 16$ & 299 \\
\hline & 13 & $41: 17$ & $59,61,368,370$ \\
\hline $40-48$ & $118,134,357,389$ & & $372-73,376$ \\
\hline $40-55$ & $\begin{array}{l}1,7-8,10-12,16 \\
23-24,138,203\end{array}$ & $41: 17-20$ & $\begin{array}{l}291,338,368-70 \\
374,377,413\end{array}$ \\
\hline & $234-35,259$ & $41: 18$ & 372 \\
\hline $40-66$ & $6,13,16,21-24$ & $41: 18-19$ & $368,372,374,376$ \\
\hline & $26,66,136,234$ & $41: 19$ & 372 \\
\hline & 246,411 & $41: 20$ & $368,371,375-77$ \\
\hline $40: 1$ & $21-22,29,59,112$ & $41: 21-29$ & $54,347,353$ \\
\hline & $254,256,292,324-$ & $41: 22$ & 376 \\
\hline & 25 & $41: 23$ & 350 \\
\hline $40: 1-2$ & $12,20-21,78,120$ & $41: 27$ & $246,281,385$ \\
\hline & $250-53,255,260$ & 42 & 54 \\
\hline
\end{tabular}




\begin{tabular}{|c|c|c|c|}
\hline $42: 1-4$ & 244 & $43: 5-6$ & $9,329-30,333-34$ \\
\hline $42: 1-9$ & 263,349 & & 394 \\
\hline $42: 4$ & 177 & $43: 5-7$ & 281, 295-96, 324, \\
\hline $42: 5$ & 253,358 & & $327-28,412$ \\
\hline $42: 5-9$ & 13 & $43: 6$ & $130,328,330,334$ \\
\hline $42: 6 b-7$ & $250,263,412$ & $43: 7$ & $281,328-29,331$ \\
\hline \multirow[t]{2}{*}{$42: 7$} & $164,263-66,268$ & $43: 8$ & $336,362,367,373$ \\
\hline & $275,280,287,330$ & $43: 8-13$ & $285,347-49,358$ \\
\hline $42: 8$ & 292 & $43: 10$ & $246,348,375$ \\
\hline $42: 9$ & $21,291,358$ & $43: 11$ & 53,279 \\
\hline $42: 10-12$ & 292,368 & $43: 12$ & 348 \\
\hline $42: 11$ & 401 & $43: 14$ & $216,285-87,290$ \\
\hline $42: 13$ & $55,59-62$ & $43: 14-15$ & $285,288,290$ \\
\hline $42: 13-14$ & $59,62,65-66$ & $43: 14-21$ & $250,279,284-85$ \\
\hline $42: 14$ & $60-62,151$ & & $293,308,412$ \\
\hline $42: 15$ & 61 & $43: 15$ & $285-86$ \\
\hline \multirow[t]{2}{*}{$42: 16$} & $61,336,365-67$ & $43: 16$ & 291 \\
\hline & 372 & $43: 16-17$ & $285,288-90$ \\
\hline $42: 17$ & 357 & $43: 16-21$ & 285,288 \\
\hline $42: 18$ & $219,346-47$ & $43: 17$ & $60,284,287$ \\
\hline $42: 18-19$ & 336 & $43: 18$ & 290 \\
\hline $42: 18-20$ & $264,344-49,373$ & $43: 18-19 a$ & 285 \\
\hline \multirow[t]{4}{*}{$42: 18-25$} & $12,266,281,285$ & $43: 18-21$ & $288,290,292$ \\
\hline & $338,344,346,349$ & $43: 19$ & $99,291,358$ \\
\hline & $351-54,362,365$ & $43: 19 b-20$ & 285 \\
\hline & 413 & $43: 20$ & $291-92,372$ \\
\hline $42: 19$ & $345-46,349-50$ & $43: 21$ & 285,292 \\
\hline \multirow[t]{2}{*}{$42: 20$} & $344,346-47,350$ & $43: 25$ & 149,229 \\
\hline & 359,367 & $43: 27$ & 359 \\
\hline $42: 21$ & 266,349 & $43: 27-28$ & 350 \\
\hline $42: 21-25$ & $88,344,349,351$ & $43: 28$ & 55,308 \\
\hline \multirow[t]{3}{*}{$42: 22$} & $250,258,266-269$ & $44: 2$ & 345 \\
\hline & $287,330,349-50$ & $44: 3$ & 371,374 \\
\hline & 412 & $44: 3-4$ & 374 \\
\hline $42: 23$ & $349-50,368$ & $44: 4$ & 374 \\
\hline $42: 24$ & $350-52,361$ & $44: 5$ & 393 \\
\hline \multirow[t]{2}{*}{$42: 25$} & $55,58,254,271$ & $44: 6$ & 286 \\
\hline & $344,352,360$ & $44: 8$ & 348 \\
\hline \multirow[t]{2}{*}{$43: 1$} & $280-81,285,292$ & $44: 9$ & 357 \\
\hline & 328 & $44: 9-10$ & 367 \\
\hline \multirow[t]{2}{*}{$43: 1-4$} & $250,279,281,293$ & $44: 9-20$ & 54 \\
\hline & $304,328,412$ & $44: 15$ & 98 \\
\hline \multirow[t]{2}{*}{$43: 1-7$} & $269,281,285,328$ & $44: 18$ & 376 \\
\hline & 344 & $44: 18-20$ & 357 \\
\hline $43: 2$ & 281,284 & $44: 19$ & 38 \\
\hline $43: 3$ & $53,281-85$ & $44: 22$ & $149,253,280$ \\
\hline $43: 4$ & $281-84$ & $44: 23$ & $289,292,401$ \\
\hline \multirow[t]{2}{*}{$43: 5$} & $328-29$ & $44: 24-45: 7$ & 48 \\
\hline & & $44: 25$ & 38,343 \\
\hline
\end{tabular}




\begin{tabular}{|c|c|c|c|}
\hline $44: 26$ & 136,385 & $47: 6$ & $55,58,144,148$ \\
\hline $44: 26-28$ & 48 & & 257 \\
\hline $44: 28$ & $81,136,280,385$ & $47: 8-9$ & 388, 397-98 \\
\hline $44: 28-45: 1$ & 281 & $47: 9$ & 56 \\
\hline 45 & 52 & $47: 10$ & 38,343 \\
\hline $45: 1$ & 264 & $47: 11$ & 355 \\
\hline $45: 1-2$ & 287 & $47: 12$ & 367 \\
\hline $45: 2$ & 356 & $47: 15$ & 362 \\
\hline $45: 4$ & 286 & $48: 1-2$ & 360 \\
\hline $45: 5-7$ & 52 & $48: 1-5$ & 354 \\
\hline $45: 6-7$ & 47,414 & $48: 1-8$ & $338,353-54,356$ \\
\hline $45: 7$ & $53,65,147$ & & $360,367,413$ \\
\hline $45: 8$ & 52,291 & $48: 2$ & 149 \\
\hline $45: 9$ & $147-48$ & $48: 3$ & $353,355-58$ \\
\hline $45: 11$ & $147-48,285$ & $48: 3-5$ & $353,358,360$ \\
\hline \multirow[t]{2}{*}{$45: 13$} & $11,175,277,281$ & $48: 3-8$ & 355 \\
\hline & 286,393 & $48: 4$ & $353,355-59$ \\
\hline $45: 14$ & 52 & $48: 5$ & $353,355-59$ \\
\hline $45: 14-17$ & 54 & $48: 6-8$ & 353,358 \\
\hline \multirow[t]{2}{*}{$45: 15$} & $47,52-53,58,279$ & $48: 7$ & 353 \\
\hline & 414 & $48: 8$ & $57,353,359-60$ \\
\hline $45: 16$ & 357 & $48: 9$ & 58 \\
\hline $45: 18-19$ & 52 & $48: 9-11$ & 57,359 \\
\hline $45: 19$ & 371 & $48: 10$ & 58 \\
\hline $45: 20$ & 357 & $48: 11$ & 58 \\
\hline $45: 21$ & 53 & $48: 14-15$ & 281 \\
\hline $45: 22$ & 52 & $48: 14-16 a$ & 358 \\
\hline $45: 23$ & 355 & $48: 17$ & $285,367-68$ \\
\hline $45: 25$ & 99 & $48: 18$ & 350 \\
\hline $46: 1$ & 356 & $48: 18-19$ & 367 \\
\hline $46: 1-2$ & 261,387 & $48: 20$ & $280,288-89$ \\
\hline $46: 1-4$ & 357 & $48: 20-21$ & 12,288 \\
\hline $46: 2$ & $275-76$ & $48: 21$ & 291,372 \\
\hline $46: 3-4$ & 326 & $49-54$ & $111,383,386,389$ \\
\hline $46: 5-7$ & 357 & & 406 \\
\hline $46: 7$ & 357,372 & $49: 1$ & 281 \\
\hline $46: 8$ & 360 & $49: 1-6$ & 244,332 \\
\hline $46: 8-13$ & 360 & $49: 1-13$ & 388 \\
\hline $46: 11$ & 281,334 & $49: 7$ & 285,332 \\
\hline $46: 12$ & 254,360 & $49: 7-13$ & 13 \\
\hline $46: 13$ & 386 & $49: 8$ & 136,403 \\
\hline \multirow[t]{3}{*}{47} & $175,257,274-75$ & $49: 8-9 a$ & 332 \\
\hline & $379,386,398,409$ & $49: 8-12$ & 332,388 \\
\hline & 413 & $49: 9$ & $37,110,265,280$ \\
\hline $47: 1$ & $386-87$ & $49: 9 b-10$ & $332-33$ \\
\hline $47: 2$ & 116 & $49: 9 b-12$ & 295-96, 298, 324, \\
\hline $47: 2-3$ & 37,398 & & $331,365,394,412$ \\
\hline $47: 3$ & 175,387 & $49: 10$ & $40,174,325,328$ \\
\hline $47: 5$ & 387 & & $332-33,372$ \\
\hline
\end{tabular}




\begin{tabular}{|c|c|c|c|}
\hline 49:11 & 309,333 & $51: 9$ & $146,162,253,274$, \\
\hline $49: 12$ & $9,130,333-34,394$ & & 290 \\
\hline \multirow[t]{2}{*}{$49: 13$} & $289,292,332,384$ & $51: 9-11$ & $270,274,289,308$ \\
\hline & 389,401 & $51: 9-52: 12$ & 274 \\
\hline \multirow[t]{2}{*}{$49: 14$} & $53,61,388-92$ & $51: 10$ & $279,291,303,307$ \\
\hline & 395-97, 407 & $51: 11$ & $119,279,292$ \\
\hline $49: 14-15$ & 392 & $51: 12$ & 274 \\
\hline $49: 14-16$ & 388,390 & $51: 12-16$ & $12,270,274$ \\
\hline \multirow[t]{3}{*}{$49: 14-21$} & $258,379,384-85$ & $51: 13$ & $258,271,278,392$ \\
\hline & 388-89, 391, 398, & $51: 13 b-14$ & $250,270,293,412$ \\
\hline & $402-3,413$ & $51: 14$ & $228,268,271-72$ \\
\hline $49: 14-50: 3$ & 388-89, 391 & $51: 17$ & $57,253,256,274$ \\
\hline $49: 15$ & 397 & & 377 \\
\hline $49: 15-16$ & 389 & $51: 17-18$ & 56 \\
\hline $49: 16$ & 187,393 & $51: 17-23$ & $55,66,256,271$ \\
\hline $49: 17$ & $190,393,395,408$ & & $273-75,379$ \\
\hline $49: 17-21$ & 388,393 & $51: 19$ & 256 \\
\hline \multirow[t]{2}{*}{$49: 18$} & $329-30,333,394-$ & 51:19-20 & $56-57,384$ \\
\hline & 95,398 & $51: 20$ & $56-57$ \\
\hline \multirow[t]{2}{*}{ 49:19 } & $94,137,258,395-$ & $51: 21$ & 57 \\
\hline & 96,403 & $51: 22-23$ & 57 \\
\hline $49: 19-21$ & $369,391,401$ & 52 & 246 \\
\hline $49: 20$ & 396,403 & $52: 1$ & $149,253,258,394$ \\
\hline \multirow[t]{2}{*}{$49: 21$} & $37,388,394,396$ & $52: 1-2$ & $274-75,395$ \\
\hline & 401 & $52: 1-6$ & $239,250,273,412$ \\
\hline $49: 22$ & $260,306,330$ & $52: 2$ & $272,275-76,387$ \\
\hline $49: 22-23$ & 389 & $52: 3$ & $145,274,276-77$ \\
\hline \multirow[t]{2}{*}{$49: 24-25$} & $133,239,261,271$ & & 279 \\
\hline & $275-76,278$ & $52: 4$ & 225,277 \\
\hline $49: 24-26$ & $269,279,293,389$ & $52: 4-5$ & 274 \\
\hline $49: 25$ & 270 & $52: 5$ & $133,239,270,277-$ \\
\hline $49: 26$ & 270 & & 78 \\
\hline \multirow[t]{2}{*}{$50: 1$} & $120,277,316,389$ & $52: 6$ & $274,277-78$ \\
\hline & $391-92,407-8$ & $52: 7$ & 392 \\
\hline $50: 1-3$ & 389 & $52: 7-10$ & 274 \\
\hline $50: 2$ & 50,303 & $52: 9$ & 137,280 \\
\hline $50: 4$ & $246,343,367$ & $52: 11$ & 274 \\
\hline $50: 4-9$ & 244 & $52: 11-12$ & 274,288 \\
\hline $50: 4-11$ & 388 & $52: 13$ & 376 \\
\hline $50: 5$ & 359 & $52: 13-15$ & $235,243,245$ \\
\hline $50: 7$ & 405 & $52: 13-53: 12$ & $17,154,234-35$ \\
\hline $51: 1$ & 34,371 & & $243,246-47,399$ \\
\hline $51: 1-3$ & 369 & & 412 \\
\hline $51: 1-52: 12$ & 235 & 53 & $10,244-46$ \\
\hline $51: 2$ & 404 & $53: 1$ & $37,120,243,245$ \\
\hline \multirow[t]{2}{*}{$51: 3$} & $119,137,150,291-$ & $53: 1-3$ & 243 \\
\hline & $92,374,384$ & $53: 1-11 \mathrm{a}$ & 235 \\
\hline \multirow[t]{2}{*}{$51: 4$} & 368 & $53: 2$ & 236,245 \\
\hline & & $53: 2-3$ & 243 \\
\hline
\end{tabular}




\begin{tabular}{|c|c|c|c|}
\hline $53: 3$ & 219 & $54: 11-17 \mathrm{a}$ & 399 \\
\hline $53: 3-4$ & 235 & $54: 13 \mathrm{~b}-17 \mathrm{a}$ & 399 \\
\hline $53: 4$ & 243 & $54: 14$ & 225 \\
\hline $53: 4-6$ & 243 & $54: 14-17$ & 27,404 \\
\hline $53: 5$ & 236 & 55 & 244, 292-93 \\
\hline $53: 6$ & $361-64$ & $55: 1$ & 371 \\
\hline $53: 7$ & $238,242,245$ & $55: 7$ & 366 \\
\hline \multirow[t]{2}{*}{$53: 7-9$} & $236-37,243,247$ & $55: 8-9$ & $363-64$ \\
\hline & 295, 399 & $55: 11$ & 355 \\
\hline \multirow[t]{3}{*}{$53: 8$} & $133,218,236-37$ & $55: 12$ & 238,401 \\
\hline & $239-40,243,245$, & $55: 12-13$ & $288,292,369$ \\
\hline & 278 & $55: 13$ & 293 \\
\hline $53: 8-9$ & 237,245 & $56-66$ & $7,11-13,16,23-$ \\
\hline $53: 9$ & $238,240,245$ & & $24,137-38$ \\
\hline $53: 10$ & 243 & $56: 1$ & 37,120 \\
\hline $53: 10-12$ & 243,245 & $56: 1-8$ & 331 \\
\hline $53: 11$ & 38 & $56: 3$ & 260 \\
\hline $53: 11 b-12$ & 235 & $56: 6$ & 260 \\
\hline $53: 12$ & 243 & $56: 8$ & 300,331 \\
\hline 54 & 48,246 & $56: 9-12$ & 362 \\
\hline $54-66$ & 143 & $57: 3-13$ & 357 \\
\hline $54: 1$ & $137,399,401-4$ & $57: 8$ & 37 \\
\hline $54: 1-3$ & $399,401,405$ & $57: 11$ & 60 \\
\hline \multirow[t]{2}{*}{$54: 1-6$} & $379,384,398-400$ & $57: 12$ & 367 \\
\hline & 409,413 & $57: 13$ & 318 \\
\hline $54: 1-8$ & 399 & $57: 15$ & 227 \\
\hline $54: 1-10$ & 385,399 & $57: 16$ & 57,316 \\
\hline $54: 1-17$ & $235,398-99$ & $57: 17$ & $51,148,315,364$ \\
\hline $54: 2$ & 195,403 & $58: 2$ & 38 \\
\hline $54: 2-3$ & 400,403 & $58: 3$ & 262 \\
\hline $54: 3$ & 137,404 & $58: 5$ & 172 \\
\hline $54: 4$ & $399,404-6$ & $58: 6-7$ & 13 \\
\hline $54: 4-6$ & $399-400,402,405$ & $58: 7$ & 173 \\
\hline $54: 4-8$ & 399 & $58: 8$ & 291 \\
\hline $54: 5$ & $401,406-8$ & $58: 9$ & $59,223,372$ \\
\hline $54: 5-6$ & 395,408 & $58: 10-11$ & 377 \\
\hline $54: 6$ & $96,391,399,408-9$ & $58: 12$ & 137 \\
\hline $54: 7$ & $50,329,399$ & $59: 2$ & 51 \\
\hline \multirow[t]{2}{*}{$54: 7-8$} & $53,379,399,406$ & $59: 3$ & 84 \\
\hline & 409 & $59: 7$ & 364 \\
\hline \multirow[t]{2}{*}{$54: 7-10$} & $48,51,53,58,66$ & $59: 8$ & 365 \\
\hline & 260,399 & $59: 8-10$ & 361 \\
\hline $54: 8$ & 50,148 & $59: 11$ & 224 \\
\hline $54: 9$ & 49,57 & $59: 12-13$ & 360 \\
\hline $54: 9-10$ & 49,399 & $59: 13$ & 225 \\
\hline $54: 10$ & 50 & $59: 17$ & 54,394 \\
\hline $54: 11$ & $57,319,383,403$ & 60 & 28,63 \\
\hline $54: 11-12$ & 395 & $60-62$ & 139,146 \\
\hline $54: 11-13 a$ & 399 & $60: 1-3$ & 63,65 \\
\hline
\end{tabular}




\begin{tabular}{|c|c|c|c|}
\hline $60: 1-22$ & 323 & $63: 18$ & $112,138,144-46$ \\
\hline $60: 4$ & $130,306,330$ & & 150 \\
\hline $60: 7$ & 150 & $63: 18-19 a$ & 142,144 \\
\hline $60: 8-9$ & 330 & $63: 19 a$ & 146 \\
\hline $60: 9$ & 130 & $64: 4$ & 142 \\
\hline $60: 10$ & $58,315,393$ & $64: 4 b-6$ & 141 \\
\hline $60: 14$ & 278 & $64: 5$ & 141,318 \\
\hline $60: 15$ & $96,391,408$ & $64: 6$ & $51,141-42$ \\
\hline $60: 21$ & 148 & $64: 7$ & $140,147-48,329$ \\
\hline \multirow[t]{2}{*}{$61: 1$} & $110,203,264,276$ & $64: 7-11$ & 139,147 \\
\hline & 280 & $64: 8$ & 148,152 \\
\hline $61: 1-3$ & $9,13,266$ & $64: 9$ & $149-51,292$ \\
\hline $61: 2-3$ & 21 & $64: 9-10$ & $138,142,149,385$ \\
\hline $61: 4$ & 137,403 & $64: 10$ & $149-51$ \\
\hline $61: 10$ & $394-95$ & $64: 11$ & $60-62,137,149$, \\
\hline 61:11 & 291 & & $151-52$ \\
\hline 62 & 62 & $65-66$ & 137 \\
\hline $62: 1$ & $60,65,151$ & $65: 1$ & 371 \\
\hline $62: 3$ & 407 & $65: 2$ & 364 \\
\hline $62: 4$ & $96,137,391,408$ & $65: 2-5$ & 357 \\
\hline $62: 4-5$ & 395,407 & $65: 11$ & 357,392 \\
\hline $62: 5$ & 408 & $65: 17$ & 291,358 \\
\hline $62: 6$ & 64 & $65: 21-22$ & 137 \\
\hline $62: 6-7$ & 63,215 & $65: 24$ & 59,372 \\
\hline $62: 10$ & 309,333 & $65: 25$ & 149 \\
\hline $62: 11-12$ & 325 & $66: 3$ & 357,364 \\
\hline $62: 12$ & 279,408 & $66: 6$ & 81 \\
\hline $63: 1$ & 272 & $66: 7-13$ & $402-3$ \\
\hline $63: 6$ & 112 & $66: 8$ & 402 \\
\hline $63: 7-14$ & 137 & $66: 10-12$ & 403 \\
\hline \multirow[t]{5}{*}{$63: 7-64: 11$} & $5,16,51,62,67-$ & $66: 12$ & 9 \\
\hline & $68,136-39,148$ & $66: 13$ & 384 \\
\hline & $152-53,234,252$ & $66: 15$ & 55 \\
\hline & $346,351,364,395$, & $66: 15-16$ & 58 \\
\hline & 411 & $66: 17$ & 357 \\
\hline $63: 8$ & 140 & $66: 18$ & 9 \\
\hline $63: 8-10$ & 140 & $66: 18-24$ & $28,66,323$ \\
\hline $63: 9$ & 140 & $66: 19-20$ & 233 \\
\hline $63: 10$ & $55,140-41$ & $66: 20$ & $231-32,260,322$ \\
\hline $63: 11-14$ & 333 & & 330 \\
\hline $63: 12-14$ & 143 & $66: 24$ & 336,360 \\
\hline $63: 14$ & 174 & & \\
\hline \multirow[t]{2}{*}{$63: 15$} & $61-62,137,150$ & Jeremiah & \\
\hline & 219 & $1: 3$ & 37 \\
\hline $63: 15-64: 11$ & 137 & $1: 4-10$ & 76 \\
\hline $63: 16$ & $140,147,329$ & $1: 6$ & 85 \\
\hline \multirow[t]{2}{*}{$63: 17$} & $55,142,145,148$ & $1: 9$ & 85 \\
\hline & $236,362,364$ & $1: 10$ & 190 \\
\hline $63: 17-19 a$ & $139,142,146$ & $2-3$ & 380 \\
\hline
\end{tabular}




\begin{tabular}{|c|c|c|c|}
\hline $2: 9$ & 316 & $10: 16$ & 144 \\
\hline $2: 13$ & $141,187,371$ & $10: 17-18$ & 180 \\
\hline $2: 15$ & 223 & $10: 17-22$ & 381 \\
\hline $2: 18$ & 176 & $10: 19$ & 83,236 \\
\hline $2: 20$ & 271,276 & $10: 20$ & 403 \\
\hline $2: 24$ & 61 & $10: 21$ & 298 \\
\hline $2: 32$ & 395 & $11: 19$ & $218,238,240,242$ \\
\hline $2: 36-37$ & 176 & $12: 7$ & $49,55,70,115$ \\
\hline 3:1 & 316 & $12: 10$ & 144,150 \\
\hline $3: 6-11$ & 380 & $12: 10-11$ & 93 \\
\hline $3: 8$ & 316,380 & 13 & 169 \\
\hline $3: 18$ & 307 & $13: 1-11$ & 178 \\
\hline $3: 22$ & 90 & $13: 17$ & $111,261,325$ \\
\hline 4:1 & 156 & 13:18-19 & 193 \\
\hline $4: 7$ & 93 & $13: 22$ & 37 \\
\hline $4: 11$ & 299,318 & $13: 26$ & 175,190 \\
\hline $4: 16$ & 114,130 & $14: 2-6$ & 370 \\
\hline $4: 19$ & 109 & $14: 6$ & 61 \\
\hline $4: 19-21$ & 381 & $14: 8$ & 117 \\
\hline 4:20 & 355 & $14: 9$ & 146 \\
\hline $4: 28$ & 96 & $14: 17$ & 111 \\
\hline $4: 29$ & 96 & $14: 17-18$ & 110 \\
\hline $4: 30$ & 395 & $14: 19$ & 110 \\
\hline $4: 30-31$ & 381 & $15: 2$ & 182 \\
\hline $5: 15$ & 114,130 & $15: 3$ & 306 \\
\hline $5: 28$ & 90 & $15: 4$ & 132 \\
\hline $6: 1$ & 82,322 & $15: 7$ & 299 \\
\hline $6: 1-2$ & 381 & $15: 8$ & 355 \\
\hline $6: 2$ & 70 & $15: 10$ & 83 \\
\hline $6: 7$ & 236 & $16: 1-13$ & $178-79$ \\
\hline $6: 8$ & 93 & $16: 10-13$ & 95 \\
\hline $6: 14$ & 228 & $16: 13$ & 161,189 \\
\hline $6: 23$ & 109 & $16: 18$ & 256 \\
\hline $6: 26$ & 111,355 & $17: 5-8$ & 341 \\
\hline $7: 15$ & 163 & $17: 7-8$ & 371 \\
\hline $7: 26$ & 355 & $17: 13$ & 117,371 \\
\hline $7: 29$ & 409 & $18-19$ & 147 \\
\hline $7: 33$ & 238 & $18: 5$ & 108 \\
\hline $8: 7$ & 224 & $18: 12$ & 364 \\
\hline 8:9-10 & 176 & $18: 17$ & 318 \\
\hline $8: 11$ & 228 & $18: 21$ & 397 \\
\hline $8: 28-23$ & 111 & $18: 22$ & 355 \\
\hline $8: 21$ & 111 & $19: 1-13$ & $107,178,192$ \\
\hline 9:9-11 & 38 & $19: 9$ & 271 \\
\hline $9: 10$ & $70,93,95$ & $19: 13$ & 108 \\
\hline $9: 10-15$ & 95 & $19: 14-15$ & 192 \\
\hline $9: 11$ & 45 & $20: 1-6$ & 192 \\
\hline $9: 12-13$ & 95 & $20: 4$ & 37 \\
\hline $9: 15$ & 70,298 & $20: 5$ & 267 \\
\hline
\end{tabular}




\begin{tabular}{|c|c|c|c|}
\hline $20: 11$ & 269 & $30: 17$ & 91 \\
\hline $21: 3-10$ & 70 & $31: 7-14$ & 326,333 \\
\hline $21: 5$ & 55 & $31: 8$ & 326 \\
\hline $21: 8$ & 218 & $31: 9$ & 238 \\
\hline $22: 5$ & 149 & $31: 10$ & 299,326 \\
\hline $22: 10$ & 193 & $31: 11$ & 326 \\
\hline $22: 10-12$ & 180,193 & $31: 15-16$ & 325 \\
\hline $22: 11-12$ & 193 & $31: 19$ & 406 \\
\hline $22: 13-19$ & 199 & $31: 21$ & 309 \\
\hline $22: 18$ & 190 & $31: 29$ & 135 \\
\hline $22: 24-27$ & 193 & $31: 34$ & 229 \\
\hline $22: 24-30$ & $192-93,242$ & 32 & $108,169,178$ \\
\hline $22: 26$ & $161,189,193,199$ & $32: 29$ & 108 \\
\hline $22: 28$ & $161,163,189,199$ & $32: 35$ & 106 \\
\hline $22: 28-30$ & 193,243 & $32: 43$ & 93 \\
\hline $23: 1-2$ & 298 & $33: 1$ & 239 \\
\hline $23: 1-8$ & 193 & $33: 4$ & 117 \\
\hline $23: 3$ & $326-27$ & $33: 5$ & 50 \\
\hline $23: 5$ & 376 & $33: 6$ & $51,91,115$ \\
\hline $23: 13$ & 361 & $33: 10$ & 93 \\
\hline $23: 19$ & 318 & $33: 12$ & 93 \\
\hline $23: 32$ & 361 & $34: 5$ & 33,190 \\
\hline $24: 5$ & 175,316 & $34: 8$ & 264 \\
\hline $24: 6$ & 190 & $34: 13$ & 249 \\
\hline 25 & 70 & $34: 22$ & 93 \\
\hline $25: 8-13$ & 70 & $36: 29-31$ & 199 \\
\hline $25: 9$ & 181,308 & 37 & 70,166 \\
\hline $25: 15$ & 56 & $37-38$ & 69 \\
\hline $25: 18-26$ & 57 & $37: 2$ & 172 \\
\hline $25: 27$ & 56 & $37: 15$ & 264 \\
\hline $26: 17-19$ & 135 & $37: 18$ & 264 \\
\hline 27 & 178,181 & $38: 1-13$ & 202 \\
\hline $27: 6$ & 70,181 & $38: 22$ & 202 \\
\hline $27: 10$ & 94,130 & 39 & 68,110 \\
\hline $27: 11$ & 260 & $39: 4$ & 110 \\
\hline $28: 3$ & 174 & $39: 7$ & 110 \\
\hline $28: 4$ & 175 & $39: 15$ & 239 \\
\hline $29: 2$ & 276 & $40: 1$ & 110,175 \\
\hline $29: 10$ & 48 & $40: 7$ & 222 \\
\hline $29: 10-14$ & 364 & $42: 13-22$ & 181 \\
\hline $29: 13$ & 371 & $43: 8-13$ & $181-82$ \\
\hline $29: 14$ & 300 & $43: 10$ & 70,181 \\
\hline $29: 20$ & 316 & 44 & 182 \\
\hline $29: 22$ & 175 & $44: 6$ & 93 \\
\hline $30-31$ & 6 & 46 & 166,181 \\
\hline $30: 8$ & 276 & $46-51$ & 101 \\
\hline $30: 10$ & $130,250,334$ & $46: 27$ & 130,250 \\
\hline $30: 14$ & 140,236 & $47: 5$ & 82,215 \\
\hline $30: 16$ & 267 & $48: 12$ & 271,320 \\
\hline
\end{tabular}




\begin{tabular}{|c|c|c|c|}
\hline $48: 38$ & 107 & $2: 1-10$ & 149 \\
\hline $48: 46$ & 275 & $2: 2$ & 190 \\
\hline $49: 32$ & 299 & $2: 3$ & 197,383 \\
\hline $49: 35$ & 114 & $2: 4-5$ & 140 \\
\hline $49: 36$ & 299, 319 & $2: 5-9$ & 382 \\
\hline $50: 4$ & 371 & $2: 7$ & 144,150 \\
\hline $50: 4-5$ & 307 & $2: 8$ & 385 \\
\hline $50: 6$ & $143,322,362$ & $2: 10$ & $82,172,387$ \\
\hline $50: 17$ & 224,300 & $2: 11$ & 111 \\
\hline $50: 33$ & $225,261,278$ & $2: 12$ & 110 \\
\hline 51 & 162 & $2: 13$ & 111 \\
\hline $51: 2$ & 286 & $2: 19$ & 110 \\
\hline $51: 8$ & 355 & 3 & 174,229 \\
\hline $51: 19$ & 144 & $3: 2$ & $48,174,333$ \\
\hline $51: 27$ & 322 & $3: 4$ & 224 \\
\hline $51: 34$ & $159,162,258,272$ & $3: 8$ & 223 \\
\hline $51: 38$ & 224 & $3: 10$ & 223 \\
\hline $51: 43$ & 117 & $3: 34$ & 164 \\
\hline $51: 44$ & 162 & $3: 38$ & 47,82 \\
\hline 51:59-64 & 178 & $3: 48$ & 111 \\
\hline 52 & 27,68 & $3: 53$ & 230,240 \\
\hline $52: 2$ & 299 & $3: 54$ & 240 \\
\hline $52: 8$ & 297 & $3: 55$ & 240 \\
\hline $52: 15-16$ & 222 & $3: 55-56$ & 230 \\
\hline \multirow[t]{2}{*}{$52: 31$} & 175 & $4: 1-2$ & 384 \\
\hline & & $4: 2$ & 148 \\
\hline Lamentations & & $4: 3-5$ & 110 \\
\hline 1 & 382 & $4: 9$ & 110 \\
\hline \multirow[t]{2}{*}{$1: 1$} & $382,384-85,387$ & $4: 10$ & 111 \\
\hline & 398,405 & $4: 11$ & 55 \\
\hline $1: 2$ & $111,382-83$ & $4: 14-15$ & 156 \\
\hline $1: 3$ & $37,255,397$ & $4: 21$ & 57 \\
\hline $1: 3-5$ & 382 & $4: 22$ & 36 \\
\hline $1: 4$ & $38,385,403$ & $5: 7$ & 135 \\
\hline $1: 5$ & 249 & $5: 11$ & 152 \\
\hline $1: 6$ & 42,332 & $5: 18$ & 45,151 \\
\hline $1: 6-7$ & 383 & $5: 20$ & 142,391 \\
\hline $1: 8$ & 175,387 & $5: 22$ & 148,152 \\
\hline $1: 8-10$ & 383 & & \\
\hline $1: 9$ & 111,383 & Ezekiel & \\
\hline $1: 10$ & $150-51,274,383$ & $1-3$ & 76 \\
\hline $1: 12$ & 236 & $1: 2$ & 175 \\
\hline $1: 13$ & 403 & $1: 13$ & 215 \\
\hline $1: 17$ & 111,383 & $2: 4$ & $96,355,360$ \\
\hline $1: 18$ & $236,249,383$ & $3: 7$ & $96,143,355,360$ \\
\hline $1: 19$ & 110,382 & $3: 7-9$ & 356 \\
\hline $1: 20$ & 110 & $3: 24-27$ & 83,178 \\
\hline $1: 21$ & 111,383 & $3: 27$ & 219 \\
\hline $2: 1$ & 384 & $4-5$ & 178 \\
\hline
\end{tabular}




\begin{tabular}{|c|c|c|c|}
\hline $4: 1$ & 393 & $18: 2$ & 135 \\
\hline $4: 1-3$ & 180 & $18: 18$ & 225 \\
\hline $4: 3$ & 180 & $19: 12-13$ & 319 \\
\hline $4: 13$ & 178,192 & 20 & 359 \\
\hline $5: 3$ & 178 & $20: 8$ & 359 \\
\hline $5: 5-17$ & 96 & $20: 12$ & 180 \\
\hline $5: 8-9$ & 71 & $20: 13$ & 359 \\
\hline $5: 12$ & 306 & $20: 20$ & 180 \\
\hline $5: 14-15$ & 71 & $20: 21$ & 359 \\
\hline $6: 5$ & 298 & $21: 23-27$ & 178 \\
\hline $6: 6$ & 197 & $22: 5$ & 84 \\
\hline $6: 9$ & 261 & $22: 11$ & 152 \\
\hline $6: 11-12$ & 178 & 23 & 381,406 \\
\hline $6: 14$ & 71,93 & $23: 3$ & 406 \\
\hline $7: 2$ & 306 & $23: 8$ & 406 \\
\hline $7: 7$ & $112-13$ & $23: 10$ & 116 \\
\hline $7: 18$ & 118 & $23: 14$ & 187 \\
\hline $7: 20$ & 395 & $23: 19$ & 406 \\
\hline $7: 21$ & 242,267 & $23: 21$ & 406 \\
\hline $7: 21-27$ & 71 & $23: 22-29$ & 381 \\
\hline $7: 22$ & 115 & $23: 26$ & 381 \\
\hline $7: 24$ & 242 & $23: 29$ & 383,387 \\
\hline $8: 6$ & 71,115 & $23: 34$ & 56 \\
\hline $8: 12$ & 49 & $23: 36-39$ & 381 \\
\hline 9:9 & 49 & $24: 21$ & 150 \\
\hline $11: 16$ & $94,130,298$ & $24: 25-27$ & 83 \\
\hline $11: 23$ & 71,115 & $25-32$ & 101 \\
\hline $12: 1-16$ & 179-81 & $25: 5$ & 45,98 \\
\hline $12: 11$ & 249 & $26-32$ & 177 \\
\hline $12: 14-15$ & 299 & $26: 4$ & 190 \\
\hline $12: 19-20$ & 71 & $26: 12$ & 190 \\
\hline $12: 20$ & 93 & $26: 20$ & 218 \\
\hline $12: 27$ & 118 & $27: 26$ & 318 \\
\hline $13: 10$ & 228 & $27: 31$ & 118 \\
\hline $13: 14$ & 190 & $28: 8$ & 272 \\
\hline $13: 16$ & 228 & $29-32$ & 166 \\
\hline $14: 8$ & 180 & $29: 3$ & 162,289 \\
\hline $14: 21$ & 306 & $29: 10$ & 332 \\
\hline $15: 8$ & 93 & 29:18-19 & 325 \\
\hline 16 & 381 & $30: 6$ & 332 \\
\hline $16: 1-8$ & 406 & $32: 2$ & $82,162,289$ \\
\hline $16: 22$ & 406 & $33: 3$ & 322 \\
\hline $16: 29$ & $241-42$ & $33: 21$ & 175 \\
\hline $16: 32$ & 381 & $33: 21-22$ & 83 \\
\hline $16: 36-37$ & 37 & $33: 23-27$ & 218 \\
\hline $16: 37$ & $116,383,387$ & $33: 28-29$ & 93 \\
\hline $17: 4$ & 241 & $33: 32$ & 218 \\
\hline $17: 10$ & 318 & 34 & 298 \\
\hline $17: 21$ & 306 & $34: 5$ & 38 \\
\hline
\end{tabular}




\begin{tabular}{|c|c|c|c|}
\hline $34: 5-6$ & 298 & $6: 1$ & 91 \\
\hline $34: 11-16$ & 326,333 & $6: 3$ & 34 \\
\hline $34: 12$ & 298 & $7: 5$ & 34 \\
\hline $34: 14$ & 326,332 & $7: 11$ & 159 \\
\hline $34: 15$ & 326 & $9: 3-4$ & 192 \\
\hline $34: 16$ & 322,327 & $9: 17$ & 226 \\
\hline $34: 21$ & 298 & $10: 7$ & 49,82 \\
\hline $34: 28$ & 267 & $13: 7$ & 223 \\
\hline $35: 4$ & 149 & $13: 8$ & 397 \\
\hline $36: 3$ & 61 & $13: 15$ & 318 \\
\hline $36: 4$ & 267 & $14: 2$ & 90 \\
\hline $36: 20$ & 278 & $14: 5$ & 90 \\
\hline $36: 34$ & 93 & & \\
\hline $36: 35$ & 404 & Joel & \\
\hline 37 & $240-41,246$ & $1: 6$ & 223 \\
\hline $37: 11$ & 240 & $1: 7$ & 175 \\
\hline $37: 14$ & 260 & $1: 13-14$ & 119 \\
\hline $37: 15-28$ & 178,307 & $1: 14$ & 119 \\
\hline $38: 12-13$ & 267 & $1: 18$ & 112 \\
\hline $39: 11$ & 113 & $2: 1$ & 60,322 \\
\hline $39: 23$ & 37 & $2: 2$ & 65 \\
\hline $39: 23-24$ & 50 & $2: 12$ & 118 \\
\hline $39: 29$ & 51 & $2: 12-17$ & 119 \\
\hline $40-48$ & 5 & $2: 15$ & 119,322 \\
\hline $40: 1$ & 175 & $2: 25$ & 286 \\
\hline $43: 9$ & 94 & 4 & $81,106,112$ \\
\hline $47: 1$ & 371 & $4: 2$ & 112 \\
\hline \multirow[t]{2}{*}{$47: 13-23$} & 322 & $4: 5$ & 151 \\
\hline & & $4: 6$ & $94,130,276$ \\
\hline Daniel & & $4: 12$ & 81,112 \\
\hline \multirow[t]{2}{*}{$9: 17$} & 144 & $4: 13$ & 261 \\
\hline & & $4: 14$ & $109,112-13$ \\
\hline Hosea & & $4: 17$ & 275 \\
\hline 1 & 178 & $4: 18$ & 371 \\
\hline $1: 9$ & 36 & & \\
\hline $1: 11$ & 140 & Amos & \\
\hline 2 & 316,380 & $1-2$ & 31 \\
\hline $2: 2$ & 307 & $1: 5$ & 106,113 \\
\hline $2: 5$ & 371 & $1: 6$ & 37,175 \\
\hline $2: 12$ & 116,387 & $1: 9$ & 175 \\
\hline $2: 15$ & 395 & $1: 11$ & 158 \\
\hline 3 & 178 & $2: 4$ & 361 \\
\hline $3: 5$ & 371 & $2: 4-5$ & 101 \\
\hline $4: 1$ & 38,316 & $2: 6-16$ & 101 \\
\hline $4: 5-6$ & 82 & $2: 16$ & 173 \\
\hline $4: 6$ & 38,215 & $3: 5$ & 268 \\
\hline $4: 10$ & 404 & $3: 6$ & 47 \\
\hline $4: 11$ & 34 & $3: 11$ & 287 \\
\hline $4: 12$ & 362 & $3: 14$ & 197 \\
\hline
\end{tabular}




$\begin{array}{ll}4: 1 & 34 \\ 4: 1-3 & 39,57,385 \\ 4: 2 & 132 \\ 4: 2-3 & 31 \\ 4: 8 & 156 \\ 4: 10 & 286 \\ 5: 3 & 60,97 \\ 5: 5 & 37 \\ 5: 12 & 283 \\ 5: 18-20 & 30,65,112 \\ 5: 27 & 39,191 \\ 6: 1 & 40 \\ 6: 1-7 & 39 \\ 6: 4-6 & 39 \\ 6: 6 & 34 \\ 6: 7 & 31,40,191 \\ 6: 9 & 97 \\ 7: 9 & 191 \\ 7: 10-17 & 191 \\ 7: 11 & 191-92 \\ 7: 12-13 & 191 \\ 7: 14-15 & 191 \\ 7: 16-17 & 191 \\ 7: 17 & 191 \\ 8: 11 & 332,372 \\ 8: 12 & 156 \\ 8: 13 & 57,372 \\ 9: 2 & 42 \\ 9: 2-4 & 156 \\ 9: 7 & 106,113 \\ 9: 9 & 156,321 \\ 9: 12 & 404 \\ & \end{array}$

Obadiah

1:20

\section{Jonah}

1

1-2

$1: 3$

$1: 4$

$1: 5$

$1: 10$

1:11-13

$1: 12$

$1: 15$

2

2:3

$2: 3-10$
175

157

161

$161,164,229$

161,188

$161,164,188,229$

161

319

$161,179,188$

$161,179,188$

213

163,223

163
2:4-5

$2: 5$

$2: 6$

$2: 7$

$3: 6-9$

$4: 8$

$4: 16$

Micah

$1: 16$

2:11

2:12

2:12-13

$2: 13$

$3: 4$

$3: 5$

$3: 6$

$3: 10$

$3: 12$

4:6

4:6-8

4:7-8

$7: 4$

$7: 19$

Nahum

1:8

$1: 13$

$2: 2$

2:4

2:8

2:13

3:5

Habakkuk

1:14-16

2:5

2:6-20

2:9-13

$3: 2$

$3: 14$

Zephaniah

1:5

$1: 11$

$1: 14$

$1: 15$

2:4
163

225,233

163

161, 163-64, 229, 258, 287

119

57

161

37

34

327

327

327

$50,59,64$

361

64

215

45

327

327

327

112

229

49

276

297

174

224

268

37, 116, 190

57

$41,215,258$

30

215

262

297

107

215

60

65

96 


$\begin{array}{llll}2: 6 & 45-46,98 & 7: 14 & 319 \\ 2: 14 & 45 & 9: 5 & 171 \\ 3: 10 & 298 & 9: 14 & 322 \\ 3: 11 & 109 & 10: 3 & 325 \\ & & 10: 9 & 130,329 \\ \text { Haggai } & & 10: 11 & 308 \\ 2: 1-2 & 172 & 12: 10 & 118 \\ & & 13: 4 & 172 \\ \text { Zechariah } & & 13: 7 & 298 \\ 1-8 & 5-6 & 14: 8 & 371 \\ 1: 12 & 92 & 14: 13 & 112 \\ 2: 1-4 & 299 & & \\ 2: 10 & 319 & \text { Malachi } & \\ 2: 12 & 149 & 2: 3 & 298 \\ 2: 13 & 308 & & \\ 3: 2 & 50 & \text { Sirach } & \\ 3: 11 & 43 & 48: 17-21 & 21 \\ 4: 7 & 108 & 48: 22 & 21 \\ 4: 12 & 321 & 48: 22-25 & 20 \\ 6: 15 & 130 & 48: 23 & 21 \\ 7: 8-14 & 96 & 48: 24-25 & 21\end{array}$

\section{New Testament}

Matthew

3:4

4:8-9

Acts

10:9
172

131

107

\section{Corinthians}

15:32

119

\section{Revelation}

3:7

198 


\section{Author Index}

Abernethy, A. T. 15, 30

Ackroyd, P. R. 2, 4-5, 7-8, 25, 70, 122, 125, 129-131, 133-35, 159-60, 201-4, 207-8, 210, 229

Aejmelaeus, A. 138-39, 145, 148

Ahn, J. J. 2-4, 6, 14

Albertz, R. 5, 7, 16, 67, 69-70, 92, 137$38,238,250$

Allis, O. T. 21

Ames, F. R. 4, 6

Baldauf, B. 338, 345, 352

Balentine, S. E. 6, 47, 50, 52-53, 59, 61

Balogh, C. 165-67, 171-74, 176-78

Baltzer, K. 20, 254, 256

Barrré, M. L. 204-6, 211-13, 215, 217, 219-22, 224, 226-28, 240

Barrett, R. 356-57

Barstad, H. 3, 23, 73, 368-69

Batchelder, C. 79, 85, 99

Becker, U. 78, 94

Becking, B. 68

Beentjes, P. C. 20

Begg, C. T. 124, 128, 134

Begrich, J. 204, 207, 211, 213, 218, 220 21, 226

Ben Zvi, E. 3, 26

Berges, U. 9, 13-14, 16, 23-25, 27, 30, 48, 52-59, 77-78, 101, 103, 122, 131, 139, $145,149,152,214,235-36,239,246-$ 47, 250-56, 261, 263, 265, 269, 283, 285-88, 290, 324-25, 328, 332, 334, $342,345-48,351-53,355-56,358$, $367,371,375,380,382,384,387$, 392-93, 397, 399, 401, 407

Berlin, A. 382, 384

Beuken, W. A. M. 13-14, 24-25, 30, 32$33,35-36,41,43-44,89,109-10$, 113-14, 117, 120, 166, 184, 207, 209,
213-14, 229, 302, 304, 307-8, 310, $312-19,321-22$

Bewer, J. A. 159

Biddle, M. E. 380, 386

Bleeker, L. H. K. 242

Blenkinsopp, J. 3, 30-33, 48-49, 52, 62$63,77,81,86,89,98,105-6,112-15$, $120,122,124,126-28,132,139,144$ $45,166,169,171-72,185,188,196$, 198, 207, 211, 217, 221, 225, 227, 229, 251-52, 265, 270-72, 274-75, 277, 290, 302-3, 310-11, 313, 317, 321, $324,330,343,345,347,349-50,360$, 363-64, 366, 369-70, 390, 393, 396$97,399,402,404,407-8$

Boda, M. J. 6, 319, 329

Borocin-Knol, S. 392

Bosman, H. 289, 317

Bosshard-Nepustil, E. 103, 195, 199

Brandscheidt, R. 52-53

Brown, M. L. 244-45

Brownlee, W. H. 19

Brueggemann, W. 48

Buhl, F. 23, 145

Burnett, J. S. 28, 47, 339

Bürki, M. 312

Byron, J. 155

Calvin, J. 22

Campbell, S. 89

Carroll, R. P. 5-6, 8-9, 14, 70, 73, 154, $160,162,182,193,336-38$

Cassuto, U. 156-58

Childs, B. S. 25, 30-31, 33, 37, 44, 52, 62, $65,78,80-81,83-84,89,99,101-5$, $107,111,114-15,120,123,125,132$, $141,144,146,165,176-77,184-86$, 195, 199, 201, 206, 209, 211, 235, 237-39, 241, 251-52, 255-56, 265, 
275, 282-83, 287, 290, 310-12, 316, $345,348,350,353,363,366-67,399$, 402, 405

Clements, R. E. $31,36,44-45,65,75,77$, $83,85,87,89,97,103,106,114,123-$ $24,128,165,170,176,184-85,190$, 196, 198, 200-1, 206, 295, 302, 305, $310-11,316,321,336,371,375$

Clifford, R. J. 30, 33

Clines, D. J. A. 237-39

Coats, G. A. $156-58$

Coetzee, J. H. 203, 211, 213, 233

Cole, R. L. 89

Cook, P. M. 166-67, 176-77, 181

Croatto, J. S. 306

Cuéllar, G. L. 10

Dahood, M. 127, 219

Daiches, S. 317-18

Darr, K. P. 15, 59

Daube, D. 131

Davidson, R. 157

Day, J. 162

de Boer, P. A. H. 207

Delitzsch, F. 26

Dempsey, C. J. 310

Dille, S. J. 15, 58, 380-81, 384, 391, 407

Dittert, K. 254-55, 268, 386

Dobbs-Allsopp, F. W. 111, 382, 385

Downs, D. 160-61

Doyle, B. 311, 313, 315, 317, 320, 322

Driver, G. R. 33, 313, 317

Driver, S. R. 236, 245

Duhm, B. 7, 23, 115, 234, 244, 316, 33132

Eggleston, C. L. 373

Elliger, K. 251-52, 255-56, 263-65, 269, 281-83, 285, 287, 290, 292, 345, 368$70,372-73,376$

Emerton, J. A. 32-33, 87

Engnell, I. 77, 84, 97, 243

Eusebius of Caesarea, 21

Evans, C. A. 19

Fabry, H.-J. 371

Fey, R. 39

Fichtner, J. 341

Fischer, G. 162, 182
Fohrer, G. 24, 166-69

Franke, C. A. 134, 386

Franzmann, M. 380, 386-87

Fretheim, T. E. 54

Friebel, K. G. 167-70, 179-81

Fullerton, K. 198

Ganzel, T. 186, 188-89, 195, 197

Gerstenberger, E. 30

Gertz, J. C. 31, 39

Gesenius, W. 23, 145

Gile, J. 297-98

Ginsberg, H. L. 186

Goldenstein, J. 89, 138-40, 142-44, 14849,152

Goldingay, J. 20, 38, 47-49, 52, 55-56, 59-63, 80, 137, 142-43, 145-46, 149, $152,235,237,240-42,252-53,261$, 263-65, 267-73, 275-77, 279, 284, 286, 291-92, 324-25, 329, 333-34, $342,344-49,351-52,354-55,358$, $363,366,370-73,376,386-88,390$, 392, 395-96, 399, 401-2, 404-5, 407

Gordon, R. P. 157

Goswell, G. 207, 209-10, 213, 231-32

Goulder, M. 242-44

Grabbe, L. L. 3

Greenberg, M. 180-81

Gregory, B. C. 9-10, 13, 266

Grimm, W. 254-55, 268, 386

Gudme, A. K. de H. 3, 6, 15, 133

Haag, H. 241-42, 244

Habel, N. 76

Hadjiev, T. S. 380

Hägglund, F. 10, 235, 237-38, 245-46

Halvorson-Taylor, M. A. 6, 11-13, 15, 71, $73,154,252,254-55,257,264,266-$ 67, 269-71, 279, 407

Hanson, P. D. 138-39, 144

Hardmeier, C. 103, 106

Hartenstein, F. 81, 251

Hasel, G. F. 76

Hays, C. B. 32, 41, 185, 187, 189-90, 215-17, 219, 222, 230

Head, P. M. 73-74

Hibbard, J. T. 295, 310-12, 314-15, 321, 323

Hjelm, I. 3, 6, 15 
Hoffer, V. 90, 203-4, 231-32

Holladay, W. 162, 179, 181-82

Hrobon, B. 80, 84

Høgenhaven, J. 6-7, 34-35, 38, 40, 65, 88, 357,361

Janssen, E. 73

Jenner, K. D. 322

Jenni, E. 198

Jensen, J. 341, 343

Jenson, P. P. 159-61, 163-64

Jeremias, C. 207

Johnson, D. G. 310-11, 317, 321

Johnston, P. S. 41, 216, 272

Jong, M. J. de 78, 94

Joyce, P. 179-180

Kaiser, O. 31-33, 65, 75, 77, 83-84, 91, 94, 97-98, 101, 103, 105, 111, 123-24, 127, 166-67, 169, 185-86, 190, 197, $215,217,243,259-60,302-3,308$, $310,313,317,321,342,366$

Kapelrud, A. S. 242-43

Kasher, R. 205, 209

Kelle, B. E. 2, 4

Kennedy, J. M. 201

Keown, G. L. 182

Kessler, J. 6, 9, 14, 67, 72-74

Kiefer, J. 3

Kim, H. C. P. 12, 43, 80, 101, 107

Klein, A. 290, 381

Klein, R. 5, 7, 174

Knibb, M. A. 2, 20

Knight, G. A. F. 24

Koenen, K. 145

Konkel, A. H. 122, 205

Korpel, M. C. 31-32, 34

Kostamo, S. K. 26-27

Kraus, H.-J. 163

Kronholm, T. 299

Kustár, Z. 15, 90, 205, 232, 235-36

Laato, A. 241

Lamb, D. T. $54-56$

Landy, F. 1, 10-11, 13, 28, 35, 38, 41-42, $44,64,75-76,78,80,82,85,90-92$, $95,98,251,337$

Lau, W. 138, 140, 145, 148-149, 151

Leene, H. 235, 311, 314, 318
Lessing, R. R. 21

Leuchter, M. 6

Levin, C. 3, 69

Lim, B. H. 19, 23

Linafelt, T. 383

Lipschits, O. 3

Locke, J. W. 54, 58

Low, M. 15, 56, 380, 382, 384, 391-92, 397, 399, 403, 406

Lucas, E. C. 339

Lund, Ø. 15, 40, 332-34, 345, 351, 36162,374

Lust, J. 296-97

Luther, M. 22

Macintosh, A. A. 63-65

Maier, C. 380, 391, 407

Marböck, J. 20

McEvenue, S. 20

McKeown, J. 158

Melugin, R. F. 25, 76, 250-51, 344

Mettinger, T. N. D. 245

Middlemas, J. 2-5, 7-8, 14, 137

Milgrom, J. 85

Miscall, P. D. 204, 233

Moberly, R. W. L. 32, 44-45

Morgan, D. F. 339, 341

Motyer, J. A. 21

Müller, R. 72, 75, 78, 90, 93

Mulzer, M. 22

Murphy, R. E. 339

Na'aman, N. 184-85

Navarro, E. F. 374

Neubauer, A. 236, 245

Nielsen, K. 15, 77-78, 97-99

Niskanen, P. 147, 408

North, C. R. 236, 241-42, 244-45, 330

Obermayer, B. 15, 54

Olson, D. T. 155, 158, 297, 339

Oosting, R. 253

Oswalt, J. N. 21, 32-33, 36, 42, 45, 64-65, $75,77,89,95,102-4,106-7,113,122$, $128,132,171-72,176,186-87,189$, $195,211,213,216,220,225,230,260$, 302-3, 305, 309, 311, 316-17, 321-22, $351,360,366-67,376$ 
Park, S.-M. S. 28, 122-23

Parker, T. C. 380

Paul, S. M. 16, 37, 43, 45, 49-50, 52, 5659, 62, 141-43, 145, 237, 239-41, 246, 251-52, 257, 261, 264-65, 268, 271, 273, 275, 278, 283, 286, 288-90, 319, 325-26, 329-30, 334, 343, 345-46, 349, 353, 363-64, 366, 370, 372, 374, $387,390,392,394,396,399,401-2$, 404-5, 407

Payne, D. 235, 237, 240-42

Perdue, L. G. 47

Petersen, D. L. 5, 96

Pfaff, H.-M. 76

Phinney, R. H. 76

Pilkington, C. 47

Pokrifka, J. 341, 371

Poulsen, F. 7, 13, 22, 27-28, 70-71, 82, 95-97, 109, 112, 114-15, 163, 177, $195,230,234,239,244,257,263,274$, $285,295,304,306-8,323,326,331-$ $33,338,349,368,373,383$

Power, C. 5, 7

Prokhorov, A. V. 78, 86

Quinn-Miscall, P. D. 204

Rendtorff, R. 76, 89, 91, 96, 251

Ridpath, I. 28

Ringgren, H. 297

Roberts, J. J. M. 321

Rothstein, D. 210, 242

Saur, M. 339

Sawyer, J. F. A. 380, 384, 387, 399, 402, 406

Schipper, J. 235-36, 244

Schleicher, M. 384-85, 393

Schmid, K. 101, 114, 199

Schmitt, J. J. 384

Scott, J. M. 2

Seitz, C. R. 7, 25, 27, 31, 76-77, 92, 97, $103,109,115,122,128-29,132,135$, $165,177,201,206,209,213-14,251-$ 52, 302, 304, 311, 316-17

Sellin, E. 241-44

Seufert, M. 21

Sherwood, Y. 160, 162, 164

Shields, M. A. 341-42
Simon, U. 22

Smart, J. D. 159-62, 253, 265, 268, 272, $338,347,350,355,375$

Smelik, K. A. D. 122

Smith, D. L. 4

Smith, G. V. 89

Smith, P. A. 138

Smith-Christopher, D. L. 4, 10, 160, 163, 249

Snaith, N. H. 245

Soggin, J. A. 240-41

Sommer, B. 383, 403

Spencer, B. J. 369-70, 372

Stassen, S. L. 399, 405

Steck, O. H. 16, 24-25, 75-77, 81, 139, 295-96

Stern, P. 347

Stökl, J. 3

Stromberg, J. 13, 16, 24, 138, 301, 306

Stuhlmueller, C. 279, 282

Stulman, L. 179, 182

Sweeney, M. 19, 23, 25, 30, 65, 75-77, 87, $97,99,101-3,106,114,122-23,125-$ 26, 166, 196-97, 205, 214, 233, 259, $301-2,310-11,316,319$

Terblanche, M. D. 269

Terian, A. 57

Thompson, T. L. 158-59

Tiemeyer, L.-S. 7, 16, 138-39, 159, 161, 286, 290, 329, 369, 383, 397

Tull, P. K. 30, 107, 383

Turner, K. J. 72, 74, 297

Uhlig, T. 15, 76, 81, 84, 89-90, 139, 143, $345,351,355-56$

van der Kooij, A. 87

van der Woude, A. 384

van Grol, H. W. M. 317

van Wieringen, A. L. H. M. 213

Vermeylen, J. 24, 198

Vincent, J. M. 23

Vogt, E. 83

von Rad, G. 203, 256

Waerzeggers, C. 3

Wagner, T. 25, 76, 80, 202, 213, 221

Walsh, J. T. 163 
Watts, J. W. 207-8, 229

Weinberg, J. 155

Weinfeld, M. 339

Weiser, A. 163

Wenham, G. J. 156, 158

Westermann, C. 37, 47-49, 52, 56, 60, 62$63,137-38,141,145,151,156-58$, 237, 239, 252, 265-66, 269, 274-78, $281,285-86,290,296,325,328,344-$ 46, 349, 363, 367-68, 388-89, 395, $399,405,408$

Wetter, A.-M. 37, 300

Whedbee, J. W. 341

Whybray, R. N. 237, 239-42

Widengren, G. 298, 300

Wildberger, H. 31-35, 44, 63, 75-79, 81$82,84,86,88-90,97-99,101,103$, $105-7,113-15,118,120,122,124$, 126-28, 130, 132, 134-35, 165-66, 169, 171-73, 176-77, 183-85, 189-90, 195-99, 205, 207, 211, 213, 217, 224$25,227,230,259-60,262,302-4$, 306-7, 310-11, 313, 317, 320-21, 343, $350,366,374,376,385$

Wilken, R. L. 22
Willey, P. T. 383, 403

Williamson, H. G. M. 1, 23-25, 31-36, 39-40, 42, 44-46, 75, 77, 96, 122, 136-38, 204, 251, 259, 302-4, 336, $341,351,385,396$

Willis, J. T. 184, 186-89, 195-96, 198, 310-11, 321

Wilson, L. 341-42

Wilson, R. R. 83

Wischnowsky, M. 111

Wolff, H. W. 39, 160, 191-92

Wong, G. C. I. 89

Wright, C. H. H. 159, 163

Wright, J. L. 4

Young, E. J. 21, 25, 35-39, 44, 52, 65, 81, $89,106-7,109,112-14,132,135,144$, $148,151,170,173-74,176,186,189$, 207, 210, 216, 220, 223, 252, 255-56, $303,311,316-17,321,366$

Young, R. A. 122

Zimmerli, W. 179, 181

Zipor, M. 355

Zobel, H.-J. 36 


\section{Subject Index}

1QIsa ${ }^{a} 19,48,55-56,58,62,106,113$, $126,145,147,171,217,222,226,228$, $237,252,260,269,275,285-86,289$, $313,324,331-32,345,354,363,374$, $390,401,407$

1QIsa ${ }^{\mathrm{b}} 63$

Aaron 92, 162, 356

abandonment 15, 49, 66, 71-72, 95, 115 , $159,242-43,260,318,329,385,388$ $89,395,402,405-13$

Abel 155, 158

Abiram 41

Abraham 22, 91, 155, 195, 277, 322, 328$29,331,355,402,404$

Adam 155, 157, 164, 316

Africa 283

Ahaz 75, 112, 116, 129, 171, 206

Ahimaaz 115

Amaziah 39, 191-92, 200

Ammon, Ammonites 45, 93, 173, 300, 302,307

Amnon 210, 402

Amos 39, 173, 191-92, 200

anger 16, 19, 47, 49-51, 54-59, 66, 92, 97, 134, 141, 148, 157, 161, 261, 274, 304,

$315,345,352,359,364,379,406,411$

Aquila 80, 213, 316

Ar 82

Arabia 63, 283

Aram 106, 113-14, 281

Ariel 106, 271

Ashdod 103, 165, 167, 170-73, 176, 182

Asherah 86

Ashkelon 82

Assyria, Assyrians 3, 22, 39, 54, 69, 107,

$112,122,125,127-28,133,165,170$ 71, 173, 176-78, 182, 184, 192, 206,
220, 224, 278, 301-2, 305, 307-9, $313-14,322,329,331,380-81,404$ Aswan 334

Babel, tower of 296-97, 338-39

Babylon, Babylonians 1, 2-4, 7, 10, 20, $25,31,36,45,54,68-71,81,93,102$, 107-8, 110-11, 113, 115-18, 121-34, $136,151,153,155,159-60,162,166-$ 67, 177, 179-83, 189, 192-94, 216, 224-25, 236, 241, 243, 245-46, 24950, 257, 259-63, 265, 267-70, 275-76, 278-79, 284-90, 292-94, 299, 305, $311-12$, 316, 328, 334-55, 358, 362, 368-69, 381, 386-88, 404, 412-13

Babylonian captivity, exile 2, 6, 9, 12, 22, 26, 31, 67-68, 123, 159-60, 178, 203, 242-43, 246, 250, 264-65

Babylonian king 42, 68, 71, 121, 127-28, 132, 134, 144, 162, 194, 243, 258, 261, $271,394,412$

banner 305, 322, 335

Baruch 181

Benjamin 197

Bethel 119, 191-92, 328

black hole 1-2, 16, 19, 28-29, 43, 46, 59, 64-67, 83, 99-100, 136, 153, 234, 250-51, 253-54, 296, 384-87, 394-95, 411-13

blessing 13, 28, 48, 62, 71-73, 128, 135, $140,143,146,256,293,340,371,374$

blind, blindness $12,15,17,34-35,88$, $115,179,263-66,269,281,285,326$, 333, 336-39, 342-49, 351-52, 361-63, 365-67, 373-78, 413-14 see also ignorance

Boaz 407

Budde, K. 158

Baal, Baals 108 
Cain 49, 154-59, 161, 164, 227, 233, 235, 240,372

call narrative, commission $75-77,87,89$, $91,93,160,215,251-52,337$

Calvin, J. 22

Canaan, Canaanites 176, 242, 297

Chaldea, Chaldeans 69-70, 93, 257, 284, 286-88, 387

cognitive metaphors $17,35,39,333,336$, $338,348,361,378,413$

compass, metaphor of the 295-96, 305, $328,334,394,404,412$

Condamin, A. 186

covenant 37, 50, 69, 71-74, 150, 196, 229 , $263,316,340,345,358,380$

creation $24,28,42,47,84,95,118,138$, $143,149,244,282,285,288-89,291-$ $92,340-41,353,355,357-58,365-66$, $368,372,377$

creator $47,52,65,83,99,102,118-19$, 147, 281-82, 285-86, 288-89, 291, $333,342,357-58,368,373,378$

cup of wrath 57, 256, 274, 377, 379

Cyril of Alexandria 22

Cyrus 11, 22-23, 52, 68, 70, 159, 250, $265,280-81,283,286-87,355-56$, 393

Daham 41

Damascus 39, 45

Daniel 119, 154

Daughter Zion 36, 42, 82, 111, 216, 273, 275-76, 380, 384, 386, 391, 407

David 20, 39, 99, 105-6, 173, 175, 188, 195-96, 205, 210, 214, 221, 306-7, 326,355

Davidic king, kingship 99, 136, 143, 153, 193, 210, 307

Davidic monarchy $70,77,99,102,123-$ 24, 132, 184, 195-99, 210, 248, 307, 322-23, 404

Day of Judgment 112

desert 40, 45, 63-64, 101, 137, 202, 285, 291-93, 309, 316, 318, 330, 332-33, $341,366,368-71,373-75,386,394$ see also wilderness

Deuteronomistic History 4-5, 69, 122, 124, 166

Deuteronomistic Law Code 72
Deuteronomistic tradition 69, 74-75, 127 , $160,166,171,350,404$

diaspora $3-6,8,10,14,68,155,160,164$, 260, 289, 296-97, 301, 304-7, 333, 369,392

disorientation $15,17,35,142,336,361$, $365,376,378-79,412-13$

dispersion 15, 17, 238, 245, 295-97, 300, $322,333,361,412-13$ see also scattering

divorce 316, 380, 391-92, 395, 397, 409 see also marriage

drinks, drinking 29-30, 33-35, 39-41, 43, 45-46, 56-57, 105, 119, 337, 341, 343, 363

Dumah 63-64

Döderlein, J. C. 22-24

Eden 150, 155, 157-58, 173, 292, 316, $374-75$

Edom 36, 54, 63-64, 158, 281, 302, $307-$ $8,330,386$

Egyptian captivity, slavery 220, 262-64, 280, 303

Eichhorn, J. G. 23

Elam 105, 113-14, 300, 302, 305, 319

Eliakim 17, 21, 102, 154, 183-84, 190, 194-200, 248, 412

Elkanah 107

empty land 5-6, 9, 14, 72-74, 153, 255, 319

Ephraim 34, 115, 302-3, 306, 310, 406 see also Northern Kingdom

Esar-haddon 210

Esau 146

Esther 68, 154

Ethiopia 165, 169-71, 174-75, 177, 182, $281,283,302,305,333$

Euphrates 286, 299, 302, 307-8, 313, 322

Eusebius of Caesarea 21

Eve 155, 164

exodus $5,8,73-74,280,288,290,303$, $307,333,355,372,375$

Exodus tradition 303, 307-8, 333, 355

Ezekiel 76, 82-83, 88, 178-182, 238, 247, 356

female imagery 379-88, 397-98, 409 see also woman, women 
fertility $71,340,368-69,373$

forced migration 4, 6, 14, 297, 300

\section{Gad 87}

gathering 9, 222, 251, 281, 295-96, 300-1, 303, 305-6, 309-12, 320-24, 326-30, 334-35, 344, 361, 364, 394, 412-13

Gesenius, W. 23

Gideon 76, 320

Gilgal 37, 39

Gog of Magog 113

Gomorrah 87

grave $42,98,161,186,188-89,192,212$, 228-29, 233, 236-38, 241-44, 247, $258,270,272,275,384$ see also pit, prison, Sheol

Greeks 94, 276

guidance $61,85,143,174,279,292,325$, $333,336,338,342-44,352-53,361$, 365-67, 372, 412-13 see also shepherd, shepherd imagery

Hagar 361

Haman 61

Hamath 302, 305, 404

Hannah's prayer 53, 401

hardening $15,34,75-76,78,85,87-92$, $95,100,131,137,139,141-42,152-$ $53,174,236,252,254,264,337-38$, $346,351,364,368,370,375,377,414$ healing $86,90-91,126,129,201,203$, 205-6, 214, 225, 227, 230-33, 236, $291,308,315,346,365,374$ see also illness

heavenly court 20,251

Hermon 39

Hezekiah 1, 11, 17, 19-22, 25, 28, 37, 63, $77,90,102,107-8,112,121-36,151$, 154-55, 161, 163, 172, 183-85, 198, 200-11, 214-19, 221-36, 240, 248, 257-58, 272, 287, 295, 335, 375, 394, 412

hiddenness $16,19,47-48,50-54,58-59$, $141,315,338$

highway $301-2,309,318,366$

Hinnom 106, 108, 192

Holiness Code 5, 72 honor 57-58, 92, 127-28, 189, 194, 196, $285,292,359,379-80,382-84,395$, $398,407,409-10,413$ see also shame Hosea 178, 361

Hoshea of Samaria 264

Huldah's prophecy 132

Ibn Ezra 22, 244-45

idols, idolatry $54,107-8,110-11,115$, 121, 179, 261, 299, 311-12, 314, 316, $318-20,323,336,338,347,353-57$, 359-62, 364, 367, 371-72, 378, 381, 413

Idumea 63 see also Edom

ignorance $34-35,39,42,46,87-88,100$, $102,254,264,282,337-41,343-44$, $347,350,352,359,361,377,413$

illness $15,73,90,121-22,124,127-29$, $135,200-2,204-7,209,211,214,229$, 231-33, 235-36, 245, 247-48

Immanuel, Immanuel-sign 202, 232

Jacob 4, 51, 55, 119, 155, 245, 258, 260, 280-82, 286, 297, 310, 313-14, 318, $320,323,325-28,331-32,334,342$, $345,350,354,370,375,389,404$

Jehoahaz 193

Jehoiachin 68-69, 123, 133, 175, 189, 191-94, 199-200, 241-45, 247, 26465,394

Jehoiakim 184, 190, 193, 199-200

Jehoshaphat, valley of 106,112

Jeremiah $69,71,76,85,88,109,111,169$, 178-79, 181-82, 192, 200, 202, 238, 242, 246-47, 271, 276

Jeroboam 191, 299

Job 148, 246-47

Jonah 42, 154-55, 159-64, 188, 201, 215 , 223-25, 229, 233, 240, 246, 258, 272, $287,319,396$

Jonathan 115

Joppa 161

Joseph 61, 151, 155, 174, 195, 249, 254, $265,269,276$

Joshua 197

Josiah 132, 135, 184, 193, 195, 198, 302

justice $1,28,30,32,44,108,115,215$, $237,239,265,342-43,349,361$ 
Kenites 158

Kidron 106

Kir 82, 105-6, 113-14

Korah 41

Lady Babylon 37, 55-56, 175, 274, 343, 379, 384, 386-87, 398, 402, 409

Lady Folly 362

Lady Wisdom 305

laments, lamentation 4, 33, 61-62, 83, 100, $111,121,137-38,157,164,172-73$, $175,213,218-19,222,225,236,240$, 252-53, 269, 271, 274, 276, 284, 290, $295,343,370,382-85,389$

leadership 176, 332-33, 336, 361, 363, 366,378

Lebanon 329, 373

Levi, Levites 254, 297

Leviathan $310,312,315,321$

Lilith 64

liturgy, liturgical 91, 137-38, 213, 251, 305,322

Lot 404

Luther, M. 22

Malchiah, cistern of 202

Manasseh 132-33, 198, 267, 306, 361

marriage 178, 380, 383, 392, 405, 407-10 see also divorce

Masoretes 188, 214, 217, 318

Masoretic text (MT) 32-33, 37, 51, 55, 58, 62-63, 97, 105-6, 126, 144-45, 164, $171,186,188,211,217,222,226,228$, $237,266,269,273,281,285-86,327$, $331,343,345,363,374,390,400,407$

Masoretic tradition 59, 171, 173, 213-14, 366

Media 113

Mediterranean Sea 305

Megiddo 193

Merodach-baladan 25, 121, 123-25, 127 , 134

Mesopotamia 113, 189, 307

Messiah, messianic figure 1, 60, 198, 202, 242, 265, 301 see also Davidic king, kingship

Micaiah, son of Imlah 264, 298

Midianites 320

Minor Prophets 297
Moab 44, 93, 111, 174, 271-72, 275, 300, $302,307,360$

Moloch 106

morning 32-34, 65, 192, 197, 212, 223 , 367 see also night

Moses 41, 72, 76, 85, 92, 155, 195, 220, 283, 297-98, 320, 340, 346, 358, 371

Mount of Olives 106

Mount Scopus 106

naked, nakedness 11, 37, 40, 116, 165, 168-70, 172-73, 175, 182, 190, 232, 248, 268, 379-83, 387, 394-95, 398, $406,410,413$

Naomi 326, 382

Nathan 87, 326

Nebuchadnezzar 25, 27, 68-70, 110, 114, $123,150,162,177,181-82,193-94$, 224

Neo-Assyrian empire 31

New Revised Standard Version (NRSV) $16,32-33,37,73,80,97,105,142$, 144-45, 162, 164, 171, 209, 211-13, $226,240,252,263,272,303,314,317$, $329,332,345,390,408$

night $7,63-65,111,180,212,222-23$, 226, 262, 318, 340-41, 383, 397 see also morning

Nile 181, 332

Nineveh, Ninevites 45, 109, 116, 119, 133, $161,174,287$

Noah 49, 175, 227, 296, 320

Nob 106

Nod 157-58, 227

Northern Kingdom 3, 69, 77, 97, 134, 191, 200, 267, 306, 310, 380 see also Ephraim

Obed 326

Oholah 116

oracles against the nations $100-1$

Palestine 169, 268-70, 329, 369

Pashur 191-2, 200

Pathros 302, 305

Paul 119

Pentateuch 71-72, 95, 154, 264, 279, 297

Persia 22, 70 
Peshitta 63, 147, 186, 263, 269, 316, 331, $374,400,407$

Pharaoh 82, 89, 92, 162, 181, 193, 195, 199, 288-90

Philistia, Philistines 61, 94, 165, 176, 275 , 302,307

pit $12,42,61,161,163-64,202,212,218$, 228-30, 233-34, 240-41, 248, 258, 270, 272, 283, 288 see also grave, prison, Sheol

praise $34,44,60,64,80,82,140,202-3$, 207, 212-13, 216, 218, 221, 229-31, 233-34, 285, 291-92, 328, 349, 375, 384, 401, 403 see also worship

Priestly ideology, texts $2,4,72-73,84$, $175,195,254$

Primeval History 158

prison 12, 37, 164, 194, 217, 230, 233, $239,243-44,249-50,254,258,263-$ 64, 272, 287, 330, 387, 390 see also grave, pit, Sheol

Promised Land 155, 219, 289, 297, 404

prophecy 4, 6-7, 21-23, 25, 30-31, 69-70, $72,89,94,103,120,123,132-35,138$, $151,165,174,176,184,191,193,228$, 277,346

Ptolemy 139

rabbinic tradition $22,55,159,202,210$, 236, 278

Rachel 325, 401

Radak 244-45

Rashi 244

Rebekah 401

Red Sea, the 220, 284-85, 288-89

redemption $8,12-13,65,91,229-30,249$ $50,254,264-65,270,278-81,283-84$, 287-89, 291-93, 304, 310, 328, 355, 407,412

remnant $11,49,60,76,97-98,133,174$, $178,180-81,217,245,267,301-4$, $307,309,326-27$

revelation $21,28,37,44,64,80,84,91$, $106,115,324,338,349,351,365,372$

Riblah 71

Ruth 154, 246, 254, 320-21, 407
Sabbath 49, 70, 72, 255

Samaria 10, 39, 49, 57, 82, 115, 172, 264, 299, 310-12, 404, 406

Samson 275, 401

sanctuary $55,92,107,112,137,142,144$ 45, 149-50, 164, 219, 267, 274, 355, 383, 404 see also temple

Sarai 401

Sargon II 103, 165, 170-71, 177

Saul 61, 188, 320

savior 57-58, 66, 117, 270, 279, 282, 29394, 348, 367

scattering 9, 15, 17, 48, 95-96, 141, 156, $178,236,260,295-301,306-8,310$ 11, 318-20, 324, 329, 334, 338, 361, $379,394,412$ see also dispersion

Seba 281, 283

Second Temple 9, 247

Seir 63-64, 146

Sennacherib 21, 27, 103, 106, 210, 384

Septuagint (LXX) 32-33, 51, 62-64, 86$87,89,98,105-6,126,142-43,145$, $147,157,172,185-86,210,218,221$, $228,237,251-52,274-75,281,286$, 297, 303, 313, 324, 331, 345, 354, 364, $370,373,385,390,400-1,407$

seraphs, seraphim 79-82, 84, 100, 251

Servant Songs 234, 241, 244

Shalmaneser 3

shame 37, 56, 116, 170-71, 175-76, 182, $189,248,257,357,379-80,383,386-$ 87, 391, 397-98, 400, 405-7, 409-10, 413 see also honor

Shebna 17, 21, 102, 154, 161, 183-92, 194-200, 241, 248, 295, 379, 393, 412 sheep $33,45,105,158-59,174,182,220$, $224,236,238,245,248,298-300,306$, 322-27, 335, 361-62 see also shepherd, shepherd imagery

Sheol 11, 19, 28-32, 36, 41-43, 46, 64, 66, 163-64, 212, 214-17, 219, 223, 229$30,233,248,258,272,287-88,295$, $363,388,411-12$ see also grave, pit, prison

shepherd, shepherd imagery $38,40,158$ $59,174-75,182,212,220-22,233$, 281, 298-300, 306, 317, 324-27, 332$35,362,365,367,378,413$ see also guidance, sheep 
Shilo 107

Shinar 302, 305

shofar 309, 322-23, 331, 335

Sidon 94, 276, 386

sign act, symbolic action 11, 82, 101, 107, 165-74, 177-83, 239, 248, 379

silence $2,16,19,29,43,46-47,59-66$, $82-83,100,123,139,142,151,153$, $178,188,192,215,223,238,241,245$, 247, 250, 253-54, 384, 387, 409, 411

Sinai 339

Sirach 20-21

Solomon 127, 130, 133, 322

Southern Kingdom 123, 301, 306, 310, 380

spirit $20-21,74,98,140,143,174,212$, 227, 262, 265-66, 330, 342, 361, 371, 373-74, 376, 400, 408

Stade, B. 158

suffering servant $17,80,90,123,154,218$, 232, 234-36, 241-42, 244, 246-48, $295,361,399,412$

Syene 331-32, 334

Symmachus 80, 316, 345, 390

Syro-Ephramite war 75

Targum 32, 65, 147, 185-86, 223, 226, $251,264,275,316,331,345,371,374$, 393,401

Tarshish 37, 161, 330

teaching 28, 265, 336, 340-44, 349, 351, $362-63,367-68,378$ see also guidance Teman 328, 334

temple $14,21,23,27,45,48,55,58,68-$ $69,71,73,79,81,84-85,97,100$, $107-8,110,112-13,115,123,128$, 130, 132-33, 136, 138, 144-45, 147, 149-53, 163-64, 172, 188, 190-92, 200, 202-4, 206-7, 216, 218-19, 222, 225-26, 230-34, 240, 246, 251, 259, $268,274,278,303,382,411$ see also sanctuary

Theodotion 80, 213, 316

Tigris 113

torah $35,97,140,339-41,343,349,351-$ 52,371

Tyre 94, 102, 109, 177, 218, 276, 386
Uzziah 79-80, 171, 240

vineyard $30,45,93,98,144,150,306$, $310-12,314,321,384$

Vulgate 51, 64, 80, 126, 143, 147, 157 , 185-86, 190, 213, 220-21, 252, 263, $269,275,287,303,316,324,331,354$, $390,400-1,407$

warrior 55, 59-62, 173, 269, 284, 324-25, 334

watchman motif $62-65,363$

Wellhausen, J. 2, 158

wilderness $40,45,58,71,73,93,101,136$, 140, 147, 149-50, 152-53, 155, 157, 174, 285, 291-93, 319, 325, 333, 341, 361-62, 366, 368-76, 386, 404 see also desert

wind $65,96,141,161,188,299-300,302$, $306-9,312,315,317-20,330-33,335$, 341

wisdom $30,38,89,266,299,333,338-43$, $349,362-63,370-71,375,377$

wisdom literature $34,38,43,338-39$

woe, woe-oracle 29-30, 33-34, 39, 47-48, $65,82-83,177,311$

woman, women $37,39,59-61,93,96$, $107,111,116,152,246,249,254,261$, 267, 274, 280, 306, 327, 379-92, 397, 399-410, 413 see also female imagery worship 39, 68, 71, 74, 81-82, 107-8, 121, $141,151,164,179,202,218,233,240$, 261, 289-90, 292, 309, 311, 313, 320, 322-23, 339-40, 353, 357, 360-61, $364,380-82$ see also praise

Yam 289

Yehud 26, 138

Zadokite community 139,144

Zaphon 328

Zedekiah 68-70, 110, 117, 133, 166, 180, 194, 199, 243

Zerubbabel 108, 159, 172 